\title{
Suomen varhaiskieliopit osana eurooppalaista traditiota
}

\author{
Digitaalisten aineistojen anti \\ nominien kuvauksen tarkastelulle
}

\author{
AINO KäRN ̈̈ JA LAURI MARJAMÄKI
}

\section{Johdanto}

Toisin kuin leksikografia, jolla on pitkä historia ja vakiintunut asema tieteen kentällä, kielioppien tutkimus eli grammatikografia ei ole Suomessa vielä laajalti tunnettu kielitieteen osa-alue. Keski-Euroopassa sitä on kuitenkin harrastettu intensiivisesti jo ainakin 1970-luvulta lähtien. Käsitteen teki tunnetuksi ilmeisesti saksalainen kielitieteilijä Dieter Cherubim Hermann Paulia käsittelevässä artikkelissaan Hermann Paul und die moderne Linguistik (1973). Grammatikografian tutkimusala jakaantuu kahtia: historialliseen ja nykypäivään suuntautuvaan kieliopin tutkimukseen. Jälkimmäinen, synkroninen grammatikografia, keskittyy nykykielioppien analyysiin ja kieliopinkuvauksen menetelmiin, kun taas historiallinen grammatikografia, jota oheinen kirjoitus käsittelee, tutkii kielioppien kehitystä eri aikoina.

Suomessakin kielioppien historiaa on tutkittu - tosin käsitettä grammatikografia ei välttämättä ole mainittu. Sakari Vihonen (1978) on tarkastellut Suomen varhaisten eli 160o-luvun kielioppien esikuvia, Kalevi Wiik (1989) suomen morfofonologian kuvauksen historiaa ja Kaisa Häkkinen (2002) suomalaisen oppikirjan vaiheita - joitakin esimerkkejä mainitaksemme. Vihonen toteaa $(1978$ : 35,185$)$ seikkaperäisessä esityksessään ensimmäisten suomen kielen oppikirjojen nojanneen aluksi vahvasti oman aikansa, siis 160o-luvun latinan kielioppeihin. Samasta asiasta mainitsee Wiik suomen morfofonologiaa käsittelevässä teoksessaan (1989: 9). He ovat päätyneet tähän tarkastelemalla lähinnä niitä historiallisia latinan kielioppeja, joita Suomessa oli saatavilla tutkimusten tekoaikana, 1970- ja 1980-luvulla. Vertailuaineiston saatavuus oli Viho-

1. Haluamme kiittää Virittäjän anonyymeja arvioijia lukuisista hyvistä kommenteista. 
sen ja Wiikin teosten syntyaikoina aivan eri tolalla kuin nykyisin. Viime vuosina varhaisten eurooppalaisten varhaispainatteiden tarjonta on nimittäin olennaisesti parantunut: useissa Euroopan maissa kirjastot ovat ryhtyneet digitoimaan ennen vuotta 1500 painettuja varhaispainatteita eli inkunaabaleita ja 1500-1700-lukujen teoksia. Näiden laajojen digitointihankkeiden ansiosta opukset, joista on säilynyt vain harvoja kappaleita Euroopan eri kirjastojen kätköissä, ovat nyt tutkijoiden käytettävissä omalla työpöydällä. Kirjastojen digitalisointihankkeet ovat siis luoneet aivan uudet edellytykset tutkia historiallisia lähteitä.

Tässä katsauksessa tarkastelemme suomen varhaisten kielioppien nominikuvauksia ja vertaamme niitä Euroopan varhaiskielioppien vastaaviin kohtiin. Kirjoituksen taustoitus ja havainnot eurooppalaisista kieliopeista nojaavat pitkälti Saksassa Herzog August -tutkimuskirjastossa meneillään olevaan tutkimushankkeeseen, jonka tavoitteena on laatia varhaisen uuden ajan kielioppeja käsittelevä digitaalinen käsikirja Handbuch frühneuzeitlicher Grammatiken (Kärnä \& Luhtala tekeillä). Ennen kuin tarkastelemme nominikuvauksia yksityiskohtaisemmin, esittelemme eurooppalaisten kielioppien perinnettä, johon suomen varhaiskieliopitkin nojaavat. Antiikista aina varhaiselle uudelle ajalle asti keskiössä olivat latinan kieliopit, ja niiden kuvausmallia sovellettiin aluksi kansankielen kuvauksissa varsin tunnollisesti.

\section{Grammatiikan historiaa}

Seuraavassa tarkastellaan lyhyesti länsimaisen kieliopin historiaa antiikin Kreikassa ja Roomassa, sen kulkua varhaisella uudella ajalla, kansankielisten kielioppien syntyä sekä 1500-luvulta alkanutta kehitystä.

\subsection{Kieliopit antiikissa ja keskiajalla}

Kielioppi, grammatica, tarkoitti Euroopassa uudelle ajalle asti pääasiassa latinan kielioppia. Kreikkalaisten filosofien kieltä koskevat pohdinnat ja grammaatikkojen teokset olivat luoneet perustan myöhäisantiikin latinan kieliopeille. Näistä tunnetuimmat ovat Aelius Donatuksen tiivis kielioppi Ars minor ja laajempi Ars maior 300-luvulta sekä Priscianuksen laaja ja erittäin seikkaperäinen teos Institutiones grammaticae noin vuodelta 550. Ars minor esittelee kahdeksan sanaluokkaa: nominit, pronominit, verbit, adverbit, partisiipit, konjunktiot, prepositiot ja interjektiot. Ne käydään läpi vuorotellen kysymyksin ja vastauksin. Joka sanaluokan kohdalla annetaan sen määritelmä, luetellaan siihen kuuluvat aksidenssit ${ }^{3}$ eli taivutuskategoriat ja sananmuodostuskeinot sekä valaistaan niitä esimerkein. Priscianus puolestaan esittelee ensin peruskäsitteet, kuten

2. Tässä kirjoituksessa on puhe Euroopan keskiajasta, jolla tarkoitetaan antiikin ja uuden ajan väliin jäävää noin tuhatvuotista ajanjaksoa (400-1400 jaa.). Suomen keskiajan katsotaan sijoittuvan noin vuosille 1100-1500. Siirtymä uudelle ajalle tapahtui eri puolilla Eurooppaa jonkin verran eri tahtiin, mutta keskiajan voi katsoa päättyneen Euroopassa noin v. 1400-1450.

3. Aksidenssi oli keskeinen käsite kieliopeissa aina uudelle ajalle saakka. Se on taivutuskategoriaa laajempi käsite, koska se kattaa myös sananmuodostuskeinot. 
kirjaimet, tavut ja lauseet, ja siirtyy sitten käsittelemään sanaluokkia ja niiden muotoja laajasti. Teos poikkeaa Donatuksen teksteistä laajuutensa, seikkaperäisyytensä ja filosofisen orientaationsa puolesta. Taipuvat sanaluokat eli nominit, verbit, partisiipit ja pronominit käsitellään ennen taipumattomia, joita ovat prepositiot, adverbit, interjektiot ja konjunktiot. Uutta on syntaksin osuus, joka muodostaa teoksen kaksi viimeistä lukua. Institutiones on kaikkiaan paljon yksityiskohtaisempi kuin kumpikaan Donatuksen kieliopeista. Se sisältää useita viittauksia kreikan kieleen ja antiikin kirjallisuuteen sekä tarjoaa usein myös vaihtoehtoisia määritelmiä.

Antiikin ajalta on periytynyt toki lukuisia muitakin kielioppeja, joita myöhemmät grammaatikot käyttivät malleina, mutta Ars minor ja Institutiones ovat tunnetuimmat ja laajimmin levinneet. Keskiajan kuluessa Donatuksen tekstejä kopioitiin yhä uudestaan, mutta niihin lisättiin muun muassa taivutusparadigmoja ja esimerkkiaineistoa, sillä antiikin aikaiset kielioppiteokset eivät enää sellaisenaan palvelleet niitä, joille latina oli vieras kieli. Samalla grammatiikka muuttui vieraan kielen opetuksen välineeksi (Law 1997, 2003: 83-85). Varhaiskeskiajalta (n. vuosilta 700-900) on säilynyt myös kielioppitekstejä, joissa näkyy kristinuskon vaikutus. Ne perustuvat Donatuksen kielioppiin, mutta antiikin kulttuuriin liittyviksi mielletyt esimerkkisanat on saatettu korvata kristinuskoon liittyvillä: Roma, Tiber $\rightarrow$ Hierusalem, Iordanis; musa $\rightarrow$ ecclesia; doctus $\rightarrow$ sanctus (Law 2003: 129-131). Tatvinus puolestaan säilytti pääosin antiikin esimerkkisanat, mutta sisällytti teokseensa eksegeettisiä pohdintoja kieliopin käsitteistä (De Marco toim. 1968). Bonifatiuksella kristillinen usko kuvastuu tekstin alkulehdellä ristin muotoon asetelluista sanoista Iesus Xhristus (Gebauer \& Löfstedt toim. 1980). Smaragdus perusteli sanaluokkien lukumäärää katolisen kirkon näkemyksellä ja käytti esimerkkeinä raamatullisia sanoja ja lauseita (Smaragdus 1986; vrt. myös Law 1982: 33-41).

Keskiajalla syntyi kautta Euroopan myös useita kommentaareja, joissa Ars minorin tekstiä täydennettiin selityksin ja paradigmoin sekä vertailtiin muihin antiikin kielioppeihin. Kielifilosofia oli tärkeä tutkimuskohde etenkin Keski-Euroopan yliopistoissa, joissa niin sanottu spekulatiivinen kielioppi tai modismi olivat vallalla 1200-luvun jälkipuolelta 130o-luvun alkuun. Pyrkimyksenä oli antaa kieliopin kategorioille Aristoteleen filosofiaan nojaavat perustelut ja tutkia merkityksen tapoja (modi significandi). Spekulatiivinen kielifilosofia (latinan sanasta speculus 'peili') etsi universaaleja kielen lakeja ja pohti, miten kieli heijastaa todellisuutta. Nämä kielifilosofiset pohdinnat eivät vaikuttaneet niinkään käytännön didaktiikkaan ja koulujen kielenopetukseen vaan ennen muuta kieliteoreettisen ajattelun kehitykseen. Oman genrensä muodostavat ne skolastiset kieliopit, joiden tarkoitus on ensisijaisesti opettaa argumentointia. Vielä 1500-luvulla laadittiin skolastisvaikutteisia kielioppiteoksia, joiden tarkoitus oli lähinnä harjoittaa ajattelua ja väittelytaitoja. Niissäkin materiaalina on tosin Donatuksen Ars minorin teksti, mutta sitä analysoidaan siltä kannalta, ovatko sen teesit perusteltuja vai eivät. Tätä genreä edustavat esimerkiksi Bartholomaeus Arnoldin Figure Donati vuodelta 1508 ja Magnus Hundtin Expositio Donati (1487), jota painettiin vielä vuonna 1511. Kouluopetuksessa Donatuksen Ars minor ja sen eri versiot säilyttivät edelleen asemansa alkeisoppikirjoina koko kirjallisessa Euroopassa.

1200-luvulta alkaen Keski-Euroopan luostari- ja katedraalikouluissa oli alkeisopetuksen jälkeen yleisimmin käytössä Alexander de Villa Dein Doctrinale (1199), 
runomuotoon puettu kieliopin säännöstö, joka oli tarkoitus oppia ulkoa. Ulkoluku oli vallitseva opetusmenetelmä, ja runomuotoiset rytmiset heksametrit palvelivat tätä tarkoitusta. Nykylukijan on vaikea käsittää tämän meille vaikeaselkoisen teoksen saamaa levikkiä ja kirjan säilymistä koulujen oppimateriaalina Keski-Euroopassa yli kolmen vuosisadan ajan, aina 1500-luvulle saakka.

Varsinkin Italian kielioppiperinteeseen vaikuttivat sydänkeskiajalta saakka aluksi anonyymeina käsikirjoituksina levinneet, myöhemmin Remigiuksen nimissä kulkeneet Ianua- tai Regulae-kielioppitekstit. Niissä analysoitiin sanaluokkia ja muotoja kysymys-vastaus-sarjoina, joissa kulloisenkin esimerkkisanan kohdalla kysytään siihen kuuluvia määritelmiä ja vastataan seuraavaan tapaan: "Mikä sanaluokka on dominus / poeta ('herra' / 'runoilija')? - Nomini. - Miksi? - Koska se tarkoittaa substanssia tai laatua erityisesti tai yleisesti ja sillä on sijamuotoja." (Anon. n. 1478.) Näin käydään läpi kaikki sanaluokat ja niihin liittyvät muotokategoriat. ${ }^{4}$ Myös Regulae-kielioppien vastaukset perustuvat pääosin Ars minorin tekstiin.

\subsection{Renessanssin ja varhaismodernin ajan grammatikografia}

Renessanssin aikana oppikirjoja ryhdyttiin jälleen uudistamaan, sillä keskiajalta periytyneisiin kielioppeihin ja niiden edustamaan klassisesta latinasta poikkeavaan kieliasuun ei oltu tyytyväisiä. Uusien kielioppien tarpeeseen vaikutti suuresti humanistien pyrkimys erottautua aiemmin vallalla olleesta oppisuunnasta, skolastiikasta, joka oli heijastunut myös kielioppikirjoissa. Doctrinale koettiin vanhentuneeksi niin latinan kieliasun, sisällön kuin opetusmenetelmänkin puolesta, ja siitä tuli humanistikielioppien esipuheiden yleinen moitteiden aihe. Renessanssin hengessä ryhdyttiin kirjoittamaan uusia kielioppeja antiikin esikuvien mukaan, ja niissä pyrittiin palaamaan antiikin alkuperäisteoksiin. Ars minor oli ollut läpi keskiajan kielenopetuksen perusteos, mutta nyt myös Priscianuksen laaja Institutiones sekä muita myöhäisantiikin kielioppeja otettiin lähdeteoksiksi, ja eri grammaatikkojen määritelmiä ja sääntöjä yhdisteltiin mahdollisuuksien mukaan. Tämän ajan kieliopit olivatkin tyypillisesti kompilaatioita, koosteita eri lähteistä.

Renessanssin vaikutus levisi Keski- ja Pohjois-Eurooppaan juuri Italiasta käsin, ja tässä nosteessa 1400-luvun italialaiset kieliopit saivat runsaasti huomiota myös oman maansa ulkopuolella. Vaikutusvaltaisiin kielioppeihin kuuluivat muiden muassa Guarino Guarinin Regulae grammaticales (synt. 1400-luvun alussa) ja Niccolò Perottin Rudimenta grammatices (painettu 1478). Alankomaissa ja Reinin varrella saivat varsin laajan levikin aluksi anonyyminä ilmestyneet, myöhemmin Wilhelm Zenders de Wertin nimissä kulkeneet Exercitium puerorum (Anon [Wert] n. 1485) ja kielioppikooste Compendium octo partium orationis (Anon. [Wert] n. 1485). Myös Johannes Despauteriuksen teokset $(1515,1518,1522)$, Thomas Linacren syntaksi De emendata structura Latini sermonis $(1527$ [1524]) sekä Philipp Melanchthonin kielioppien eri versiot - ensimmäinen ilmestyi 1525

4. Jo Priscianukselta on säilynyt harjoituskielioppi Partitiones, jossa analysoidaan Aeneis-runoelman ensimmäisten rivien sanoja yksi kerrallaan ja määritetään niiden sanaluokka sekä niihin kuuluvat aksidenssit. 
ilman tekijän suostumusta ja seuraavana vuonna hänen luvallaan - olivat laajalle levinneitä ja suosittuja Keski-Euroopassa. Syntaksiosio ilmestyi ensin erillisenä vuonna 1526, myöhemmin yhdessä muoto-opin kanssa. Melanchthonin teokset erosivat aikalaisistaan kokonsa, typografiansa ja ennen muuta tavoitteidensa puolesta. Aiemmat kieliopit olivat suurikokoisia, fraktuuralla painettuja opuksia, Melanchthonin kielioppi taas pieni, oktaavokokoinen, toisin sanoen taskuun sopiva, sirolla kursiivilla painettu oppikirja, jonka pyrkimyksenä oli antaa vain kieliopin peruskäsitteistö ja pääsäännöt sekä johdattaa oppilaat mahdollisimman pian latinankielisten tekstien pariin. Se tarjoaa runsaasti esimerkkisanoja ja niiden taivutuksia, ja kirjoittaja välttää teoreettista pohdintaa. Eräs syy esityksen suppeuteen oli se, että oman kielioppinsa rinnalla Melanchthon edellytti "pojilla olevan aina Donatus käsissään” (1527: [F7r]). ${ }^{5}$

Kaikkien näiden latinan kielioppien perusrakenne pysyi ennallaan ja oli verrattain yhdenmukainen, joskin osien laajuus saattoi vaihdella. Johdannossa oli usein kieliopin määritelmä: kielioppia pidettiin taitona puhua ja kirjoittaa oikein. Tässä kohdin sanamuoto tosin saattoi vaihdella ja esiintyi eri näkemyksiä siitä, oliko kielioppi ars 'taito,' 'taide' vai scientia 'tiede.' Oppialan määritelmää seurasi jako kirjaimiin, tavuihin, sanoihin ja lauseeseen tai puheeseen. Varsinaisessa kielioppiosiossa, jonka otsikkona on Etymologia mutta joka nykytermein ilmaistuna kuvaa morfologiaa, käsiteltiin ensin sanaluokkien taivutuskategoriat ja sanamuodostusta. Kieliopin toinen osa oli lauseoppi, jossa samat sanaluokat ja niiden muodostamat sanaliitot ja kongruenssi käytiin läpi. Joissakin laajemmissa oppikirjoissa oli lisäksi ortografia- ja prosodiaosio sekä kirjeenkirjoitusopas tai tyylioppi. Kieliopin tarkastelutapa ei ollut siis 1500-luvulle tultaessa juurikaan muuttunut antiikin ajoista. Joitakin seikkoja, kuten substantiiviadjektiivi-jaottelu, esitettiin selkeämmin, paradigmoja ja esimerkkisanoja saattoi olla runsaammin, ja erityisesti syntaksin kuvausta kehitettiin.

\subsection{Kansankielten kieliopeista}

Opetustilanteissa oppilaiden äidinkieli oli varmasti läsnä jo varhaisimmista ajoista asti, ja kirjallisetkin merkinnät kansankielen käytöstä grammatiikassa ulottuvat myöhäisantiikkiin. Jo karolingiselta ajalta on säilynyt niin sanottuja interlineaari- ja konsekutiivikielioppeja, joissa latinankielisen Ars minor -tekstin rivien välissä tai sen jäljessä oli kansankielinen käännös. Näitä käytettiin opetuksessa läpi keskiajan (Henkel 1988: 67). Ne loivat osaltaan pohjaa Euroopan kehittyvälle kaksi- tai monikielisten koulukielioppien genrelle.

Kansankieliset tekstielementit, joita varhaisella uudella ajalla alkoi yhä yleisemmin esiintyä alkeiskieliopeissa, esiintyvät joko käännösvastineina harvinaisemmille esimerkkisanoille tai joskus kieliopin termeille tai määritelmille, mutta myös laajempaa kielten systeemien vertailua esiintyi. Tästä on enää lyhyt matka Euroopan kansankielten kielioppeihin, jotka ovat syntyneet latinan kieliopin mallin mukaan mutta eri maissa jonkin verran erilaisista lähtökohdista. Esimerkiksi italian kielen varhaiset kieli-

5. Suomennokset ovat kirjoittajien. Folionumeroitujen teosten sivunumerot on merkitty hakasulkeisiin silloin, kun niitä ei ole painettu teokseen, mutta ne voi päätellä laskemalla. 
opit syntyivät nousevan renessanssi-humanismin hengessä, ja niiden lähtökohtana oli oman kielen arvostus ja tarve osoittaa sen olevan yhtä merkittävä kuin latina. Kulttuurisuhteet ja konfessioon liittyvät motiivit olivat myös tärkeitä tekijöitä kielten opiskelussa: uskonpuhdistus suosi oman kielen käyttöä, mutta myös vastauskonpuhdistus otti äidinkielen omaan ohjelmaansa (Glück 2002: 83). Myös merkantilismi, kauppasuhteiden kehitys ja yhteiskunnalliset muutokset antoivat voimakkaan sysäyksen kielenoppimiseen ja eri kielten oppikirjojen laatimiseen. Ensimmäiset saksan kieltä käsittelevät kieliopit esimerkiksi kirjoitettiin latinaksi pääasiassa kieltä opetteleville ulkomaalaisille. Näitä kansankielen kielioppeja syntyikin erityisesti nousevissa kansallisvaltioissa ja sellaisilla alueilla, joilla vallitsi vilkas, kielirajat ylittävä kanssakäyminen, sekä kaksikielisissä yhteisöissä, joihin Suomikin lukeutui. Varhaiset suomen kieltä käsittelevät 160oja 1700-lukujen oppikirjat kirjoitettiin latinaksi. Niitä ei selvästikään ole tarkoitettu alkeisopetukseen eikä äidinkielen oppikirjoiksi, vaan ne on kirjoitettu ulkomaalaisille, lähinnä emämaa Ruotsista tuleville virkamiehille (vrt. Häkkinen 2000a: 809). Petraeus nimeää kohderyhmäkseen ruotsalaiset, saksalaiset, skotit ja muut ulkomaalaiset (1649: [4-5]). Vastaavanlaista kohderyhmän nimeämistä löytyy useista Euroopan kieliopeista, muun muassa Albert Ölingeriltä (1573: iiii) ja Laurentius Albertukselta (1573: a2v).

Näissä Euroopan eri kielten varhaisissa oppikirjoissa kuvauskielenä oli latina - olihan se tuolloin Euroopan papiston, virkamiesten ja oppineiden yhteinen kieli ja avain kaikkiin korkeampiin opintoihin. Kansankielten kieliopit noudattivat aluksi tarkoin latinan kielioppien mallia ja käyttivät sen jaotteluita. Näin tekivät ensimmäiset italian, ranskan, hollannin, saksan, englannin ja tšekin kieliopit ${ }^{6}$, ja myös niiden metakielenä oli useimmiten latina. Varhaisella uudella ajalla alkoi näkyä pyrkimystä eri kielten ominaispiirteiden huomioimiseen, mutta varsin kauan säilyi useissa kieliopeissa esimerkiksi latinan mukainen sijajärjestelmä, ja edelleen melkein kaikkien Euroopan kielten koulukieliopeissa on lähestulkoon samat (alun perin kreikkalaisilta saadut) sanaluokat.

\subsection{Grammatikografian uudet trendit 1500- ja 1600-luvulla}

1500-luvun lopulla ja 1600-luvulla kansankielten kieliopeissa alkoi näkyä vähittäistä irrottautumista latinan mallista. Ylipäätään kansankieliä alettiin tarkastella lähemmin ja niitä kuvattiin järjestelmällisemmin. Latinan kieliopit säilyttivät tosin edelleen asemansa, mutta niiden sisällössä painottui entistä enemmän syntaksin kuvaus.

Vuonna 1559 ranskalainen filosofi ja loogikko Petrus Ramus julkaisi oman latinan kielioppinsa, Grammaticae libri quatuorin, sekä siihen liittyvän teoreettisen tutkielman Scolae grammaticae. Kielioppi nautti jonkin aikaa suurta suosiota ja synnytti oman koulukuntansa. Tämän ramistisen mallin olennainen piirre oli keskittyminen muotokriteereihin sekä dikotomiat: kaikki kategoriat jaettiin kahtia ja näin syntyneet alaluokat

6. Euroopan kielioppien varhaisvaiheista on paljon kirjallisuutta. Mm. laaja hakuteos Handbücher zur Sprach- und Kommunikationswissenschaft (HSK) käsittelee tätä aihepiiriä eri kielten näkökulmasta. Latinan vaikutus eri kielien oppikirjoihin on esitetty sivuilla 742-743 (varhaiset italialaiset), s. 765 (varhaiset ranskalaiset), s. 773 (varhaiset englantilaiset), s. 789 (varhaiset hollantilaiset), s. 797 (varhaiset tšekin kieliopit) ja s. 779-782 (varhaiset saksalaiset). 
taas kahtia ja niin edelleen. Ramus sai joitakin seuraajia muissa maissa: esimerkiksi Saksassa Wolfgang Ratken malli noudatti erittäin johdonmukaisesti samaa kaavaa.

Tämän ajan huomattaviin kielenkuvauksiin kuuluvat myös Franciscus Sanctiuksen Minerva (1587), Julius Caesar Scaligerin De Causis linguae Latinae (1540), Gerald Vossiuksen laaaja, moniosainen teoskooste De arte grammatica libri septem (1635) sekä Antoine Arnauldin ja Claude Lancelotin Grammaire Générale (1660) eli niin sanottu Port-Royalin kielioppi. Näistä viimeksi mainittu edusti kenties selkeimmin universaalikielioppia. Kaikkiin edellä mainittuihin liittyy rationalismin nousu: uskottiin, että kielen lainalaisuudet ovat perusteltavissa järjen avulla ja että ne perustuvat yleispäteviin logiikan sääntöihin. Vaikka edellä mainitut teokset ovat - Port-Royalin kielioppia lukuun ottamatta - ilmestyneet ennen Petraeuksen vuonna 1649 julkaisemaa ensimmäistä suomen kielioppia, näyttää siltä, että niiden vaikutus ei ole tuolloin vielä ulottunut Suomeen.

\subsection{Kielitieteen historian lähteet digitaalisella aikakaudella}

Edellä esitetty suppea tiivistelmä Euroopan kielioppien vaiheista on samalla katsaus kielitieteen historiaan, sillä kielitieteen ja grammatikografian historia oli aluksi pitkälti yhtenevä.7 Poikkeuksen muodostavat keskiajan filosofiset traktaatit, jotka kuuluvat niin filosofian kuin kielitieteenkin oppihistoriaan.

Oppihistorian piirissä lähteiden saatavuus on tietenkin ensiarvoisen tärkeää. Keskeiset antiikin ja keskiajan lähdeteokset ovat pääosin saatavana moderneina editioina, nykylukijalle helposti luettavaan asuun toimitettuina, ja ne ovat tarjolla kirjastoissa - antiikin latinalaiset kieliopit jopa verkossa luettavissa (CGL). Toisin on varhaisen uuden ajan kielioppien laita. Niitä ei ole - yksittäisiä poikkeuksia lukuun ottamatta - editoitu, vaan ne ovat tähän asti olleet tarjolla vain tiettyjen kirjastojen rariteettikokoelmissa ja erikoislukusaleissa. Tämä on varmasti vaikuttanut siihen, että uuden ajan alku on jäänyt kielitieteen historiaa käsittelevissä teoksissa vähälle huomiolle. Nyt tilanne on muuttunut: Ranskassa kansalliskirjasto digitoi varhaispainatteita, ja Englannissa on laaja varhaisia teoksia käsittävä verkkoluettava kokoelma EEBO. Merkittävä eurooppalainen tutkimusrahoittaja Deutsche Forschungsgemeinschaft on tukenut varhaisten painatteiden digitointia Saksassa, ja eri aikakausiin erikoistuneet kirjastot ovat saattaneet kirjaharvinaisuutensa verkkoon. Esimerkiksi Bayerische Staatsbibliothek (BSB) Münchenissä on digitoinut runsain määrin 1400-luvun inkunaabeleita sekä 1500-luvun painatteita, ja Herzog August Bibliothek (HAB) Wolfenbüttelissä on erikoistunut keskiaikaan ja varhaismoderniin. Tällä tutkimuskirjastolla on useita jo julkaistuja ja meneillään olevia digitaalisia tutkimushankkeita. ${ }^{8}$

7. Kielitieteen ja grammatikografian yhteinen historia ilmenee myös Pohjoismaiden lingvistiikan historiaa käsittelevästä teoksesta The history of linguistics in the Nordic countries (Henriksen, Hovdhaugen, Karlsson \& Sigurd toim. 2000), jossa varhaisen uuden ajan lingvistiikkaa edustavat varhaiset kieliopit.

8. Myös Kansalliskirjastolla on meneillään digitointihankkeita: Projektissa "Kirjahistoria" on digitoituja oppikirjoja Ruotsin vallan ajalta, ja "Aarteet"-kokonaisuudesta löytyy muun muassa Vhaelin Grammatica Fennica. Lisäksi jotkut Kansalliskirjaston kokoelmiin lukeutuvat teokset löytyvät verkosta muiden kirjastojen digitoimina. 
Näihin digitointihankkeisiin on liitetty myös tutkimusprojekteja. Nyt puheena olevan aihepiiriin, kielioppien historiaan liittyen on HAB:ssa parhaillaan meneillään projekti, jossa yhteistyössä kieliopin historian tutkijoiden kanssa laaditaan verkkokäsikirjaa Handbuch frühneuzeitlicher Grammatiken (ks. Kärnä \& Luhtala tekeillä). Käsikirjassa esitellään lukuisia varhaisen uuden ajan kielioppeja ja niiden tekijöitä, lähteitä, julkaisuympäristöä ja -ajankohtaa sekä reseptiota. Koska käsikirja ilmestyy verkossa, voi kuvailtuja oppikirjoja lukea digitoituina näköispainoksina. HAB digitoi kielioppiteokset ja liittää aineiston käsikirjaan. Tämä käsikirja - ja vastaavat hankkeet, jotka tuovat varhaispainatteita nykylukijan saataville - ovat omiaan taustoittamaan myös suomalaista oppihistorian tutkimusta.

\section{Suomen kielen varhaiset kieliopit ja niiden tutkimus}

Myös varhaisimmat suomen kieltä käsittelevät latinankieliset kieliopit, jotka ovat säilyneet, noudattivat latinan kielioppien perinteistä mallia ja kuuluvat näin ollen yhteiseen eurooppalaiseen traditioon. Näitä ovat Eskil Petraeuksen (1649), Matias Martiniuksen (1689) ja Bartholdus Vhaelin kielioppi (painettu postuumisti 1733)9 sekä hiljattain löytynyt, 170o-luvulta peräisin oleva Rudimenta (ks. Lauerma \& Randén toim. 2012). Lukuun ottamatta Rudimentaa, joka on säilynyt vain käsikirjoituksena, ne muistuttavat myös ulkoisesti eurooppalaisia kaksi- tai monikielisiä esikuviaan 1500-luvulta - jopa otsikointeja ja kirjasintyyppejä myöten. Erityisen selvästi yhtäläisyys näkyy, kun asettaa rinnatusten varhaiset latinalais-saksalaiset kieliopit, esimerkiksi Hermann Bonnuksen tai Nathan Chytraeuksen sekä Arvid Tideruksen latinalais-ruotsalaisen ja Suomen kaksi- tai kolmikieliset teokset. Ne ovat jo painoasultaan samankaltaiset: kaikissa eri kielet erotellaan kirjasintyypeillä. Petraeuksen kieliopissa suomenkieliset sanat on painettu fraktuuralla, latina antiikvalla. Kolmikieliset Martinius ja Vhael käyttävät fraktuuraa sekä suomenettä ruotsinkielisiin tekstinosiin.

Vihonen teki väitöskirjassaan (1978) perinpohjaisen selvityksen kieliopeista, jotka ovat saattaneet olla suomen kielen ensimmäisten kielioppien lähteinä. Vertailussa olivat mukana Nathan Chytraeuksen Grammatica Latina (vuosien 1634 ja 1687 laitokset), Arvid Tideruksen samannimiset teokset (1640 ja 1731) sekä eräitä 160o-luvun kielioppeja, joita hän piti Donatuksen ja Melanchthonin teoksina. Vihonen (mt.) vertaili jossain määrin suomen kielioppeja myös Stahlin ja Gösekenin viron sekä Ölingerin, Albertuksen ja Johannes Clajuksen saksan kielen varhaiskielioppeihin, joiden kuvauskielenä on latina.

Eri osioiden laajuuksia vertailemalla Vihonen päätyy esittämään, etteivät ainakaan saksan ja viron kielen kieliopit ole toimineet suorina malleina; sen sijaan Petraeuksella ja Martiniuksella on melko lailla "Melanchthonia", Tiderusta ja Chytraeusta vastaavat jakaumat. Vihonen on tuonut yhtäläisyydet järjestelmällisesti esiin ja päätyy to-

9. Vhaelin kieliopin syntyajankohta ei ole tiedossa. Se on voinut syntyä hänen toimiessaan triviaalikoulun opettajana Oulussa ja Vaasassa 1689-1692 tai hänen Ruotsin vuosinaan 1714-1717. Joka tapauksessa se on kirjoitettu ennen vuotta 1723. 
teamaan, että oletettavasti Petraeus on käyttänyt mallinaan lähinnä Chytraeuksen ja Tideruksen kielioppeja sekä lisäksi muitakin tuon ajan latinan kielioppeja - olihan hän opiskellut pitkään Euroopan eri yliopistoissa ja tutustunut muihinkin kuin RuotsiSuomen koulujärjestyksen määräämiin oppikirjoihin. (Vihonen 1978: 35-37). Tämä on varsin looginen tulos, sillä Vihosen käyttämät teokset ovat samalta vuosisadalta kuin ensimmäiset suomen kieliopit ja ne olivat myös koulujärjestyksen määräämiä kieliopin oppikirjoja (mts. 11).

On kuitenkin tärkeää huomata, että eräät Vihosen käytettävissä olleet 160o-luvun painokset ovat merkittävästi etääntyneet originaalista eivätkä ne näin ollen välttämättä edusta tekijänsä alkuteosta. Uuden ajan alussa ei ollut lainkaan harvinaista, että teoksia toimitettiin useaan otteeseen. Tekijä itse saattoi korjailla oppikirjaansa seuraaviin painoksiin, siitä saatettiin tehdä eri painopaikoissa erilaisia versioita tai se saattoi ilmestyä jopa täysin eri asussa uutena laitoksena. Erityisesti Melanchthonin kielioppi muuttui huomattavasti eri toimittajien käsissä. Alkujaan vähän yli satasivuinen tiivis esitys, jonka tarkoitus oli lähinnä esitellä keskeiset kieliopin käsitteet ja antaa esimerkkejä taivutusparadigmoista, ilmestyi myöhemmin 400-, jopa yli 500-sivuisena, sisällöltään tyystin erilaisena. Etymologia eli morfologiaosio paisui huomattavasti, ja sen koko konsepti muuttui. Eri laitoksia markkinoitiin kuitenkin Melanchthonin nimissä, koska merkittävän uskonpuhdistajan nimen käyttö turvasi suuremman menekin. Kieliopin maine perustui tekijänsä tunnettuuteen varsinkin protestanttisissa maissa, ja siitä tuli Saksassa, Pohjoismaissa ja monissa Itä-Euroopan maassa kielioppien esikuva. Vuosina 1634 ja 1661 painetut Erasmus Schmidtin toimittamat editiot, joita Vihonen käyttää, ovat ilmestyneet vuosikymmeniä, jälkimmäinen jopa sata vuotta Melanchthonin kuoleman jälkeen. $\mathrm{Ne}$ edustavat uudistettuja laitoksia eikä niitä voi samastaa Melanchthonin alkuperäiseen teokseen, sillä ne ovat saaneet - kuten kansilehdellä kerrotaan - vaikutteita esimerkiksi Sanctiukselta (1587) ja Scaligerilta (1540) sekä muiden muassa Petrus Ramuksen (1559) didaktiikasta, mikä muuttaa sekä niiden rakennetta että tavoitteita huomattavasti.

Käytettävissä olleet lähteet ovat vaikuttaneet merkittävällä tavalla Vihosen käsitykseen syntaksin kehityksestä, mistä seuraa myös joitakin ongelmia. Melanchthonin alkuperäisen syntaksiosion rakenne ei poikkea juurikaan perinteisten kielioppien lauseopin dispositiosta. Siinä ei ole Vihosen (1978: 25-26) mainitsemaa jakoa syntaxis intransitiva ja transitiva -osiin eikä vastaavaa jakoa nominien ja verbien kohdalla, vaan se on rakenteeltaan jopa yksinkertaisempi kuin Chytraeuksen. Samat kahdeksan sanaluokkaa, joita tarkasteltiin morfologiassa, käsitellään uudestaan lauseopissa ja niistä annetaan numeroituja sääntöjä. Näin ollen havainto, että syntaksin rakenne olisi 150o-luvun lopulla selkiytynyt (mts. 25-26), ei vastaa täysin todellisuutta, vaan tilanne on ainakin Melanchthonin kohdalla päinvastainen. Alkuperäinen, vuoden 1527 syntaksi, oli yksinkertainen ja jokseenkin selkeä, myöhemmät, esimerkiksi Erasmus Schmidtin toimittamat 160o-luvulla ilmestyneet laitokset (joita Vihonen käytti), olivat rakenteeltaan monimutkaisempia vaikkakin kattavampia. Ilmeistä onkin, että Melanchthon halusi kirjoittaa mahdollisimman helppotajuisen lauseopin. Hän ammensi syntaksinsa vaikutteita humanisteilta, muiden muassa Jakob Heinrichmannilta. Myöhempiin editioihin, jotka poikkeavat tästä alkuperäisestä tavoitteesta, on koottu vaikutteita monista eri lähteistä. Ne ovat siis heterogeenisiä kompilaatioita, joissa ilmenee ramistinen vaikutus. 
Huomiota kiinnittää myös se, että Vihosella on tiettyä epäjohdonmukaisuutta lähteinä käytettyjen teosten merkintätavoissa. Donatus-nimellä käsitellään erilaisia teoksia, jotka kyllä pohjaavat Aelius Donatuksen Ars minor -tekstiin, mutta eivät ole mainitun tekijän laatimia, vaan usein anonyymeinä laitoksina ilmestyneitä kaksikielisiä koulukielioppeja. Chytraeus mainitaan Grammatica Latina -nimellä ilmestyneiden teosten tekijänä (ks. Chytraeus 1621, 1667), mutta sama tekijä on myös joidenkin kaksikielisten Donatus sive progymnasmata -teosten laatija (anon. 1646 [Chytraeus]). Vaikka Vihonen tuokin tämän ohimennen esille (1978: 10), lukijalle jää hämäräksi, kenen laatimia kieliopit ovat, kun niitä nimitetään tekstissä erottelematta "Donatuksiksi”. Myös lähdeluettelossa ne on lueteltu Donatuksen kohdalla (mts. 7, 196). Vihonen pitää (mts. 7) vuonna 1625 ilmestynyttä "Donatusta" viimeisenä Chytraeuksen tämännimisistä kieliopeista. Tosiasiassa sitä painettiin ainakin vielä vuonna 1646.

Seuraavassa tarkastelemme lähemmin varhaisia suomen kielen kielioppeja eurooppalaista taustaa vasten käyttäen esimerkkinä nominien kuvausta. Humanistikielioppia edustavat tässä Niccolò Perottin Rudimenta grammatices (1476), Heinrichmannin Grammaticae institutiones (1506), Brassicanuksen Institutiones Grammaticae (1508) ja Philipp Melanchthonin Grammatica Latina (1526); Hermann Bonnuksen Elementa partium orationis $(1603)^{10}$ ja Nathan Chytraeuksen Grammatica Latina $(1621)^{11}$ on niin ikään otettu mukaan tarkasteluun. ${ }^{12}$

Latinan alkeiskielioppien alkuperäisiä, varhaisia painoksia on säilynyt vain vähän. Ne kuluivat oppilaiden käytössä, eikä niitä ilmeisesti pidetty niin suuressa arvossa, että niitä olisi järjestelmällisesti taltioitu kirjastoihin. Esimerkiksi varhaisin säilynyt Chytraeuksen kieliopin laitos on painettu postuumisti noin 40 vuotta ensipainoksen jälkeen, joten varmaa tietoa senkään alkuperäisestä sisällöstä ei ole. Voidaan arvella, että se muistutti edeltäjänsä, Bonnuksen latinalais-alasaksalaista teosta Elementa partium orationis (n. vuodelta 1528), koska ne perustuvat samoihin lähteisiin. ${ }^{13}$ Tästäkin oppikirjasta on säilynyt vain postuumeja laitoksia, vuosilta 1575-1603.

\section{Nominien kuvaus varhaisissa suomen kieliopeissa}

Nominien kuvaus noudatti samaa kaavaa antiikista aina uudelle ajalle asti. Kuvaus sisältää yleensä seuraavat elementit: määritelmän, sekä toisinaan termin etymologian,

10. Vuoden 1603 laitoksen teoksesta Elementa partium orationis on toimittanut Nicolaus Vorstius.

11. Vuoden 1621 laitoksen on toimittanut Johann Caselius. Chytraeus laati myös Pohjois-Saksassa useissa kouluissa käytetyn latinalais-alasaksalaisen alkeisoppikirjan Donatus sive Progymnasmata grammaticae latinae pro classe tertia (ks. anon. 1646 [Chytraeus]) sekä aihepiireittäin järjestetyn latina-alasaksa sanaston Nomenclator latino-saxonicus (1582).

12. Jos ei erikseen mainita, Melanchthon on tässä artikkelissa aina (tekijän tarkistama) vuoden 1527 , Bonnus vuoden 1603 ja Chytraeus aina vuoden 1621 painos; Perottilta käytämme vuoden 1476, Heinrichmannilta 1506 ja Brassicanukselta vuoden 1508 painosta. Nämä kieliopit esitellään tarkemmin verkkokäsikirjassa (ks. Kärnä \& Luhtala tekeillä).

13. Bonnuksen kieliopin tarkka syntyajankohta ei ole tiedossa. Tekijä tuli Tanskan kuninkaan hoviin Holsteinin herttua Juhanan opettajaksi vuonna 1528 ja laati tälle latinan oppikirjan. Sen painoon saattamisesta huolehti kuitenkin Hermann Bonnuksen poika Arnold. (Spiegel 1864: 1213.) Teosta painettiin ainakin vuosina 1575, 1576, 1579 ja 1603. 
aksidenssien eli muotokategorioiden luettelon ja niiden tarkemman käsittelyn. Donatus määritteli nominit sekä muodon että merkityksen puolesta sanoiksi, joilla on sijataivutus ja jotka tarkoittavat esinettä tai asiaa - erityisesti tai yleisesti. Tämän määritelmän ottivat sellaisenaan omiin oppikirjoihinsa muiden muassa Perotti, Heinrichmann ja Brassicanus.

Melanchthonin kieliopissa sitä on supistettu jättämällä viittaamatta sijataivutukseen ja appellatiivi-propri-jakoon (proprie communiterve eli erityisesti tai yleisesti) ja toteamalla lyhyesti, että nominit ovat sanoja, jotka ilmaisevat asiaa, eivät toimintaa (que rem significat, non actionem). Tämä sama, puhtaasti merkitykseen perustuva määritelmä löytyy myös Bonnukselta, joka on lisännyt siihen käännöksen ja esimerkkisanat. Chytraeus puolestaan esittää (distributionaalisen) lisäyksen, jonka mukaan nominin eteen voidaan asettaa kansankielinen (!) artikkeli ${ }^{14}$. Siihen turvautuu Martiniuskin: "Nomen est, quo res nominatur, \& cui finnonicè praeponi potest, yxi vel see. ut: yxi ihminen / een menniskia / homo." Samoin tekee Rudimenta; vain esimerkkisanat ovat toiset: 'usko' ja 'totuus' (Randén 2012: [52-53]). Vuosien 1634 ja 1661 "Melanchthon"-kieliopit ovat kompilaatioita eri lähteistä: ne lisäävät alkuperäiseen määritelmään esimerkkisanat ja Petrus Ramukselta omaksutun vaihtoehtoisen määritelmän (1661: 12-14): "Nomen, est pars orationis, quae rem significat, non agere aliquid aut pati: ut Homo, Mensa, animal. Vel est pars orationis, rem primò significans sine tempore."15 Petraeus ja Vhael eivät määrittele nominia.

Osana sanaluokan määritelmää tai välittömästi sen jälkeen käsitellään nominien jakoa yleis- ja erisnimiin sekä adjektiiveihin ja substantiiveihin. Tässä kieliopit eroavat toisistaan. Osa pitää nominien jakautumista appellatiiveihin ja propreihin ensisijaisena, toiset puolestaan jakoa substantiiveihin ja adjektiiveihin. Ensin mainittu jaottelu painottaa enemmän merkitystä kuin syntaksia tai taivutuskategorioita - taipuvathan latinan proprit periaatteessa aivan samalla tavalla kuin appellatiivitkin, kun taas adjektiiveille leimallista on komparaatio ja mukautuminen pääsanan genukseen. Donatuksella ja Priscianuksella yleis- ja erisnimijako oli ollut ainoa sanaluokan kattava kahtiajako, ja tätä noudattavat Heinrichmann, Brassicanus ja Melanchthon. Adjektiivien yhä itsenäisempi asema heijastuu puolestaan Perottin, Bonnuksen, Chytraeuksen sekä Petraeuksen ja Martiniuksen kieliopeissa. Myös vuoden 1661 [1634] "Melanchthon" pitää adjektiivi-substantiivi-jakoa ensisijaisena. Vhael ja Rudimenta tulevat toimeen ilman appellatiivi-käsitettä eivätkä niin muodoin esittele sanaluokan teoreettista jakoa.

Tämän jälkeen kieliopeissa luetellaan nominin aksidenssit eli muotokategoriat. Donatuksella ja Heinrichmannilla niitä on kuusi: qualitas, comparatio, genus, numerus, figura ja casus. Brassicanus sen sijaan lisää Priscianukselta peräisin olevan kategorian species sekä deklinaation ja päätyy näin kahdeksaan muotokategoriaan. Melanchthon luettelee (kenties epähuomiossa) vain viisi aksidenssia mutta käsittelee seitsemän: komparaation, genuksen, numeruksen, figuran, kaasuksen, deklinaation sekä specieksen. Hän on siis jättänyt (Donatukseen verrattuna) qualitas-aksidenssin pois ja lisän-

14. Opetustilanteissa kansankielen hyödyntäminen on varmasti vanhaa perua, ja painetuissa kieliopeissa tämä nominien määritystapa tunnetaan jo 1400-luvulta.

15. "Nomini on sanaluokka, joka tarkoittaa asiaa, ei toimintaa tai sen kohteena olemista, kuten ihminen, pöytä, eläin; tai se on sanaluokka, joka tarkoittaa ensisijaisesti asiaa ilman ajan ilmaisua." 
nyt sen sijaan deklinaation ja specieksen. Samoin tekee Chytraeus. Sama luettelo on myös Petraeuksella ja Martiniuksella. Bonnus puolestaan jättää specieksen käsittelemättä nominien yhteydessä. Vhael (1733: [12-13]) on poistanut genuksen listastaan ja keksinyt sen sijaan soveltaa täysin uutta kategoriaa, statusta, omistusliitteiden kuvaamiseen. Näistä poikkeavat selvästi vuoden 1634 ja 1661 "Melanchthonit", jotka nojaavat Ramuksen malliin: siinä jaetaan aksidenssit yleisiin, kaikkia sanaluokkia koskeviin, ja erityisimpiin, vain jotain yksittäistä sanaluokkaa koskeviin.

Komparaatio, genus, numerus, kaasus ja deklinaatio ovat nykylukijallekin tuttuja käsitteitä. Niiden rinnalla esiintyvät figura, species ja qualitas. Termi figura kuvaa sitä, onko sana yhdistetty (compositum) vai yhdistämätön (simplex); species merkitsee jakoa kantasanoihin (primitiva) ja johdoksiin (derivativa). Qualitas puolestaan on termi, jota Donatus käyttää appellatiivi-propri-jaosta; valtaosa varhaisen uuden ajan kieliopeista pitää sitä osana nominin määritelmää eikä omana aksidenssinaan. Donatuksen laajempi Ars maior (Holtz 1981: 615-617) käsittelee specieksen osana qualitas-kategoriaa. Tosin hänen species-luokkansa eivät liity lähtökohtaisesti johtamiseen, vaan useat niistä ovat puhtaasti semanttis-loogisia.

Donatus käsittelee aksidenssit seuraavassa järjestyksessä: qualitas, comparatio, genus, numerus, figura, casus; Priscianuksella (GL 2: 57) puolestaan järjestys on species, genus, numerus, figura, casus. Varhaisella uudella ajalla järjestys noudattelee monesti Priscianusta - kuitenkin siten, että komparaatio esiintyy luettelon kärjessä ja deklinaatio on erotettu kaasuksen alaisuudesta omaksi aksidenssikseen. Chytraeus (1621: 6-7) eroaa muista käyttäessään järjestystä genus, numerus, casus, declinatio, comparatio, figura ja species. ${ }^{16}$ Myös suomen varhaisissa kuvauksissa on omaksuttu sama järjestys. Uuden järjestyksen voisi otaksua ennakoivan taivutuksen ja johtamisen selvempää erottelua, vaikka sellaista perustetta ei eksplisiittisesti missään mainitakaan.

Seuraavaksi tarkastelemme, miten eri aksidensseja käsitellään yhtälälä latinan, toisaalta varhaisissa suomen kieliopeissa.

\subsection{Genus}

Latinan kieliopeissa erotettiin usein kolmesta seitsemään sukua: maskuliini, feminiini ja neutri sekä näiden yhdistelmiä eli erilaisia tapauksia, joissa sama sana saattaa esiintyä useammansukuisena. Suvun määrittämistä konkretisoitiin erisukuisin demonstratiivipronominein. ${ }^{17}$ Varhaisen uuden ajan latinan kieliopeissa on useampisivuiset luettelot suvun määräytymisestä merkityksen ja sananloppujen perusteella. Tässä suomen kieliopit luonnollisesti pääsivät vähemmällä.

Petraeus (1649: [11]) esittää, ettei sukujen välistä erottelua tunneta suomessa, ja Martinius (1689: [18]) määrittää suomelle yhden suvun ("Yxi Mies - - Yxi Waimo - -

16. Tämä aksidenttien järjestys löytyy joistakin 1600 -luvun hakuteoksista, esim. Levinus Hulsiuksen monikielisen sanakirjan kielioppiosiosta, mutta vasta sen kuudennesta ja sitä seuraavista painoksista (1644). Suoraa yhteyttä Chytraeuksen ja Hulsiuksen välillä on vaikea osoittaa; samanlaisuus voi perustua myös yhteiseen lähteeseen.

17. Latinan kielessä ei ole varsinaista kieliopillista artikkelia, toisin kuin kreikassa, jossa käytäntö oli kenties luontevampi. 
Yxi Elein”). Myös Rudimenta (Lauerma \& Randén toim. 2012: [52-53]) mainitsee, että suomalaiset eivät erota sukuja, vaan käyttävät sekä miehistä että naisista pronominia hän. Tämä huomautus nomini-kohdassa osoittaa, ettei kieliopillisen ja biologisen suvun käsitteiden ero ollut tekijälle aivan selvä. Sinänsä se, että genuksesta oli ylipäätään puhetta, ei ole lainkaan outoa, sillä olihan äidinkielenään ruotsia tai saksaa puhuville syytä mainita, ettei suomessa ole kieliopillista sukua. Vhael (1733: [12]) puolestaan huomauttaa heti aksidenssiluettelon jälkeen, ettei suomessa tunneta erottelua eri sukuihin.

\subsection{Numerus ja numeruksen anomaliat}

Numeruksen määrittely on ymmärrettävästi kaikissa kieliopeissa melko yhdenmukainen ja lyhyt: lukuja on kaksi, singularis ja pluralis. Täydellisyyden nimissä on joissain kieliopeissa otettu kantaa erisnimien monikkomuotoihin, mikä oli kielifilosofisesti kiistanalainen kysymys jo antiikissa (Luhtala 2005: 109). Brassicanus (1508: [E4r]) kehottaa lukijoitaan: "Sanokaa siis, että erisnimillä on sekä yksikkö että monikko. Oppineilla on antaa teille tästä lukuisia todisteita." Koska varhaiset suomen kieliopit pyrkivät suppeisiin esityksiin, ne vain mainitsevat yksikön ja monikon ja antavat niistä pari esimerkkiä. Näin tekevät esimerkiksi Perotti, Heinrichmann ja Bonnus.

Donatus ei käsittele singulare ja plurale tantum -tapauksia Ars minor -kieliopissaan, mutta sekä Ars maior että Priscianuksen Institutiones luettelevat yleisimpiä tantumsanoja numeruksen yhteydessä; luettelot on jäsennelty genuksittain. Näin tekee vielä Brassicanuskin, kun taas Heinrichmann, Melanchthon ja Chytraeus pyrkivät esittämään kaikenlaiset anomaliat (eli luvun, suvun, sijan ja taivutuksen suhteen epätäydelliset tai epäyhtenäiset paradigmat) omana kappaleenaan vasta itse aksidenssien jälkeen. Melanchthon ja Chytraeus mainitsevat eksplisiittisesti, että heidän kielioppinsa ovat deklinaatioihin asti käsitelleet kielen säännöllistä, analogista, rakennetta.

Tätä latinan kielioppien tarjoamaa analogia-anomalia-mallia vasten voi selittää sen, että Petraeus ja Martinius suovat sinänsä suppeissa esityksissään numeruksen anomalialle oman kappaleen. Kaasuksen ${ }^{18}$ saati genuksen anomalioilla ei suomessa ymmärrettävästi ole samaa merkitystä kuin latinassa. Martiniuksella numerus eli luku seuraa deklinaatiota kuten Heinrichmannilla, Melanchthonilla ja Chytraeuksella. Tähän Petraeuskin lienee pyrkinyt, mutta numerusta käsittelevä kohta on vahingossa vaihtanut paikkaa komparaation kanssa. ${ }^{19}$ Vhael sen sijaan ei mainitse numeruksen anomaliaa.

Petraeus jakaa luettelonsa yksiköllisiin ja monikollisiin sanoihin. Hänen luettelonsa on vain sivun mittainen ja nojaa sanavalinnoiltaan selvästi latinan kielioppeihin. Toki suomen ja latinan singulare tantum -tapaukset ovat nykynäkökulmastakin varsin samankaltaisia, mitä tulee sellaisiin abstraktisanoihin kuten hyveellisyys, kunnia ja

18. Latinassa jo perusteiden hallitsemiseksi on tunnettava keskeisten epäsäännöllisten tai taivutukseltaan vaillinaisten nominien paradigmoja (esim. vis, jolla ei ole yksikön genetiiviä, tai locus, joka on yksikössä erisukuinen kuin monikossa). Perinteisesti lueteltiin Donatusta ja Priscianusta seuraten taipumattomat (aptota), vain yhdessä sijassa (monoptota), vain kahdessa sijassa taipuvat (diptota) jne. omina ryhminään.

19. Vihonen (1978: 97) pitää Petraeuksen kappalejakoa tarkoituksellisena: näin komparaation rooli osana taivutusta vahvistuisi. 
niin edelleen. Vihosen (1978: 99) mukaan Petraeuksen luettelo olisi paria poikkeusta lukuun ottamatta omaksuttu Tiderukselta (1731 [1640]). Suurin osa Petraeuksen luetteloimista sanoista löytyy tosin myös Chytraeukselta (1621: 43-46).

Martiniuksen esitys (1689: [30-31]) on noin kaksi kertaa Petraeusta laajempi, eikä se ole pelkkä luettelo, vaan tantum-sanoja on jaoteltu käyttäen loogis-filosofisia käsitteitä in genere (sukuihin, luokkiin) sekä in specie (lajeihin). Luokkien jäsentely (proprit, iät, hyveet ja paheet, nesteet, numeraalit) ja niihin liittyvät otsakkeet ovat sananmuotojaan myöten lainaa Chytraeukselta. Tosin Martinius on keksinyt siirtää numeraalit plurale tantum -otsakkeen alta (jonne ne latinan kieliopissa kuuluvat) osaksi singulare tantum -tapauksia. Hän lisää kuitenkin hieman epätarkasti, että monikollistakin käyttöä esiintyy. Tällä hän viitannee lukujen monikolliseen taivutukseen plurale tantum -sanojen kanssa. Rudimenta (ks. Lauerma \& Randén toim. [s. 52-53]) mainitsee pluralia tantum -käsitteen nominien määritelmän yhteydessä ja toteaa niiden olevan nomineita, vaikka sana $Y x i$ ei voikaan esiintyä niiden edellä.

\subsection{Kaasus}

Taulukossa 1 esitetään kootusti, miten eri kieliopeissa kuvataan kaasus- eli sijataivutusta.

Taulukko 1.

Kaasuksen määritelmä.

\begin{tabular}{l|c|c|c} 
& Määritelmä: sananlopun & & \multicolumn{2}{c}{$\begin{array}{c}\text { Sijojen } \\
\text { lukumäärä }\end{array}$} \\
\hline Kaielioppi & + & - & 6 \\
\hline Priscianus & + & + & 6 \\
\hline Perotti (1476) & - & + & 6 \\
\hline Beinrichmann (1506) & + & + & $7^{20}$ \\
\hline Melanchthon (1527) & - & - & 6 \\
\hline Bonnus (1603) & - & - & 6 \\
\hline Chytraeus (1621) & - & + & 6 \\
\hline "Melanchthon" (1661) & + & + & 6 \\
\hline Petraeus (1649) & - & - & 6 \\
\hline Martinius (1689) & - & - & 6 \\
\hline Vhael (1733) & - & - & 6 \\
\hline Rudimenta & - & - & 6 \\
\hline
\end{tabular}

Sijamuotojen käsittely alkaa kieliopeissa yleensä kaasusten määrän toteamisesta ja niiden luettelosta. Donatuksen Ars minor luettelee latinan kuusi sijaa (nominatiivi, genetiivi, datiivi, akkusatiivi, vokatiivi ja ablatiivi); samoin tekevät muutkin

20. Seitsemäs sija on ablativus absolutus. 
vertailukielioppimme. Kaasuksen käsitteen tai yksittäisten kaasusten käytön määrittelyä ei Donatuksesta löydä. Priscianus (GL 2: 183) sen sijaan antaa kaasuksen merkitykseksi sanan lopun vaihtelun deklinaatioiden mukaisesti, ja häntä mukailee Perotti (1476: a6v). Vain osa kieliopeista kuvailee yksittäisten sijojen käyttöä; esimerkiksi Melanchthonin (1527: [c2V-c3r]) nominatiivin määritelmä on seuraavanlainen: "Nominativus, Prima vox est qua nominamus rem., ${ }^{21}$

Kuten Melanchthonilla, myös Brassicanuksella ja Heinrichmannilla yksittäisten sijojen kuvaus on lähinnä sijan nimityksen etymologinen parafraasi. Bonnuksella (1603: a4v) tämä selvennys on alasaksaksi. Varhaisissa suomalaiskieliopeissa ei ole kaasuksen määritelmää: niissä on vain ilmoitettu sijojen lukumäärä ja nimet. On kenties luotettu siihen, että kaasukset olivat tuttuja latinan tunneilta tai ymmärrettävissä jo nimiensäkin perusteella. Sitä paitsi sijojen käsittely ei rajoitu kieliopeissa tähän kohtaan, vaan vastauksia kysymykseen "Milloin mitäkin sijaa käytetään" on etsittävä syntaksiosiosta, jossa Petraeus ja Martinius käyvät pitkälti latinan kielioppia toistaen kaasusten kongruenssin ja rektion läpi.

Sijamuodot ovat luonnollisesti seikka, johon huomio kiinnittyy, kun verrataan varhaisia oppikirjoja suomen nykykielioppiin. Latinan kuuden sijamuodon malli koettiin ylipäätään niin sitovaksi, että se oli mallina myös muiden kansankielten kieliopeissa: useissa varhaisissa englanninkin kieliopeissa esitetään sama kuuden sijan järjestelmä (esim. Lily 1534). Myös varhaiset saksan kieliopit lukivat vokatiivin saksan kaasussysteemiin, Albertus jopa ablatiivinkin (Albertus 1573: [f7r]; Ölinger 1573: 23). Näissä kielissä latinan malli johti siis useamman sijan esittämiseen kuin kielessä oli muotoja. Tilanne oli päinvastainen suomessa, jossa sijamuotoja on enemmän kuin latinassa. Petraeuksen ja Martiniuksen käyttämää sijajärjestelmää on jo kuvattu Vihosen (1978: 91) ja eritoten Wiikin (1989: 21-23) tutkimuksissa. Wiik pyrkii havainnollistamaan, miten varhaiset suomen kieliopit kuvasivat jo kaikki keskeisimmät sijamuodot muoto-opillisesti, mutta jaottelivat ne käännösvastineiksi latinan sijoille. Tätä on havainnollistettu taulukossa 2.

Taulukko 2.

Suomen sijat Petraeuksella ja Martiniuksella (vrt. Wiik 1989: 21-23).

\begin{tabular}{l|l}
$\begin{array}{l}\text { Latinan mukainen suomen sijajärjestelmä } \\
\text { (Petraeus 1649; Martinius 1689) }\end{array}$ & $\begin{array}{l}\text { Muotojen vastaavuus nykyjärjestelmässä } \\
(\text { ISK 2004) }\end{array}$ \\
\hline nominativus & nominatiivi, partitiivi, essiivi, translatiivi \\
\hline accusativus & genetiivi, partitiivi, illatiivi \\
\hline genetivus & genetiivi \\
\hline dativus & allatiivi \\
\hline ablativus & inessiivi, elatiivi, adessiivi, ablatiivi \\
\hline vocativus & nominatiivi, partitiivi \\
\hline
\end{tabular}

Petraeuksen esitys sijoista on erittäin suppea, vain vajaan sivun mittainen. Hän luettelee kaasukset ja huomauttaa tapauksista, joissa yhtä sijaa vastaa useampi pääte

21. "Nominatiivi on ensimmäinen muoto, jota käytämme asioiden nimeämiseen." 
(terminatio) tai joissa useampi sija saa saman päätteen. Martinius on hieman täydentänyt Petraeusta ablatiivin käsittelyn osalta: toisin kuin Petraeus, hän esittää kaikki sijojen muoto-oppiin liittyvät huomiot deklinaatioiden yhteydessä, niin kuin latinan kieliopitkin yleensä tekevät. De Casibus -otsakkeen alla on pelkästään luettelo suomen kuudesta sijamuodosta.

Sijataivutus on toki yksi perustavanlaatuisimmista eroista suomen ja latinan nominien muoto-opissa, ja sikäli latinan mallissa pitäytyminen on varhaiskielioppien helposti tunnistettavissa oleva heikkous. Ei kuitenkaan voi väittää, että Petraeus ja Martinius poikkeaisivat latinan mallista minkään muunkaan aksidenssin kohdalla - genusta lukuun ottamatta. Itse asiassa sijajärjestelmä on niitä kieliopin harvoja kohtia, joissa Petraeus ja Martinius ovat yrittäneet luoda uusia kieliopillisia muotokategorioita: he määrittelevät jonkinlaisia kaasusten alaluokkia toisaalta Aristoteleen syiden, toisaalta latinan prepositioiden vastineiksi. Näin esimerkiksi nykyistä elatiivia vastaa ablatiivin alakäsite, materiaalinen syy (causa materialis, esim. talo on puu/sta.) tai inessiiviä latinan prepositio in. Rudimentan esitys käsittää esimerkkisanojen 'ihminen', 'mies' ja 'jumal' taivutuksen kuudessa sijassa.

Vhaelin sijajärjestelmä (1733: [14]) eroaa perustavalla tavalla edeltäjistään. Jos vokatiivin säilyttämistä, komitatiivin puuttumista ja nimitysten poikkeavuutta (esim. illatiivi on Vhaelilla penetratiivi) ei oteta lukuun, hänen neljätoista sijaansa vastaavat suurin piirtein nykykielioppien sijoja. Vhael (1733: [17-18]) mainitsee jopa osa- ja totaaliobjektin ja esittää pääpiirteittäin niiden jakautumisen nominatiivin, akkusatiivin ja genetiivin kesken. Kuten Häkkinen (200ob: 174, 182) toteaa, latinan kieliopin kategorioista ei kuitenkaan tässä vaiheessa haluttu luopua kokonaan; voisi myös ajatella niitä pidetyn kaikille yhteisenä esitietona, jota ilman lukijoiden olisi ollut vaikeampi ymmärtää selitettävän kielen rakennetta. Vokatiivi on osana suomen kuvausta vielä Strahlmannin $(1816: 14,18,20)$ ja Judénin (1818: 21-22) kieliopeissa.

\subsection{Deklinaatio}

Donatus ei määrittele deklinaatiota eikä erota sitä omaksi aksidenssikseen; Priscianuksella puolestaan esiintyvät samat viisi deklinaatiota kuin myöhemmilläkin grammaatikoilla. ${ }^{22}$ Perotti selostaa deklinaatiot kaasuksen alaisuudessa; muissa tarkastelluissa kieliopeissa ne ovat oma aksidenssinsa. ${ }^{23}$ Sijojen muoto-oppi käsitellään luonnollisestikin deklinaation yhteydessä, joka esimerkiksi Melanchthonin kieliopissa (1527: c3f1) vie noin kolmanneksen (44 sivua) nominien käsittelystä. Deklinaatiota käsiteltiin humanistikieliopeissa laveasti, sillä periaatteena oli luetella deklinaatioittain mahdolliset yksikön nominatiivin loppukirjaimet ja antaa näistä kaikista esimerkkejä. Toisaalta latinan deklinaatioiden määrittämiseksi on tiedettävä myös yksikön genetiivi, koska

22. Koska Donatuksen kieliopit tarjoavat kieliopillisen käsitteistön latinaa äidinkielenä puhuville, ne eivät juuri anna taivutussääntöjä. Priscianuksen Insitutio de nomine et pronomine et verbo edustaa puolestaan varhaista regulae-kielioppia, joka sisältää perustiedot deklinaatioista ja konjugaatioista.

23. Heinrichmann ei mainitse deklinaatiota alun aksidenssiluettelossaan, mutta se on huomattavan itsenäisessä asemassa genuksen (eikä kaasuksen) jälkeen ja vastaa muutenkin asettelultaan muita aksidensseja. 
siitä saa taivutusvartalon muiden sijojen muodostamiseksi. Esimerkiksi ensimmäisen deklinaation sanat päättyvät nominatiivissa $-a,-a s,-e,-e s$, ja genetiivin pääte on -ae. Toisen deklinaation sanat päättyvät puolestaan -us, -um, -er, -ir, -ur, -eus, ja genetiivin pääte on -i. Taulukko 3 kuvaa latinan deklinaatioita, taulukko 4 sitä, miten Martinius ne kieliopissaan esittää.

\section{Taulukko 3.}

Latinan deklinaatiot.

\begin{tabular}{c|l|l} 
Deklinaatio & Yks. genetiivin pääte & Yks. nominatiivin päätteet \\
\hline I & $a e$ (musa, musae) & $a, a s, e, e s$ \\
\hline II & $i$ (servus, servi) & $u s, u m, e r$, ir, ur, eus \\
\hline III & is (rex, regis) & $a, e, o, c, l, n, r, s, t, x$ \\
\hline IV & $u s$ (senatus, senatus) & $u s, u$ \\
\hline V & ei (dies, diei) & es \\
\hline
\end{tabular}

\section{Taulukko 4.}

Suomen deklinaatiot Martiniuksen mukaan (1689: 19-29).

\begin{tabular}{c|l|l} 
Deklinaatio & Yks. genetiivin pääte & Yks. nominatiivin päätteet \\
\hline I & an (herra, herran) & $a, a s$ \\
\hline II & än (leipä, leiwän) & $\ddot{a}$, äs \\
\hline III & in (portti, portin) & $i$ \\
\hline IV & en (äni, änen) & $i, e, s, n, u$ \\
\hline V & un (apu, awun) & $u$ \\
\hline VI & on (aaldo, aallon) & $o$ \\
\hline VII & $\ddot{n} n($ limpsiö, limpsiön) & $\ddot{o}$ \\
\hline VIII & yn (kyty, kydyn) & $y$ \\
\hline
\end{tabular}

Petraeus ja Martinius tukeutuvat taulukon 3 kuvaamaan latinan malliin. Petraeus jakaa nominintaivutuksen kahdeksaan deklinaatioon (genetiivin perusteella -an, -en, -in, -on, -un, -än, -ön ja -yn -deklinaatioihin). Hän ei kuitenkaan luettele mahdollisia nominatiivin sananloppuja, minkä Martinius taas täydellisyyden nimissä tekee (ks. taulukkoa 4). Pyrkimystä suomen vartalonvaihtelujen huomioimiseen voi havaita erityisesti Martiniuksen neljännessä deklinaatiossa, joka kuvaa ainakin i:n ja e:n vaihtelun (esimerkkisanat nimi : nimen, mies : miehen, sydän : sydämen). Wiikin mukaan (1989: 40-42, 57-59) suomen 160o-luvun kuvaukset ovat "terminativistisia", eli ne eivät vielä luokittele päätteitä suffikseiksi, vaan puhuvat ainoastaan sanojen mahdollisista lopuista (terminatio). Tämä toteamus pätee kaikkiin antiikin, keskiajan ja varhaisen uuden ajan kielioppeihin.

Voi hyvin kuvitella ensimmäisten suomen kieliopin laatijoiden innostuneen huomatessaan suomessa olevan esimerkksi ruotsia tai saksaa enemmän kieliopillisia muo- 
toja, jotka voi asettaa latinan sija- ja deklinaatioluokkien vastineiksi. Martinius vieläpä lisää ensimmäiseen eli $a$-deklinaatioon $a s$-päätteiset sanat, jolloin hän voi esittää vierasperäisten, lähinnä kreikkalaisten henkilönimien taipumista latinan tapaan ensimmäisen deklinaation mukaan. Tätä on havainnollistettu taulukossa 5.

Taulukko 5.

Latinan ja suomen 1. deklinaatio (Petraeus 1649; Martinius 1689).

\begin{tabular}{lll|lll}
\multicolumn{4}{c}{ Latina } & \multicolumn{2}{c}{ Suomi } \\
\hline Sija & yks. & mon. & yks. & mon. \\
\hline Nominatiivi & Lucas $^{24}$ & Lucae & Lucas $^{25}$ & Lucat/Lucaita \\
\hline Genetiivi & Luc.ae & $\begin{array}{l}\text { Luca- } \\
\text { rum }\end{array}$ & Luc.an & Lucasten \\
\hline Datiivi & Lucae & Lucis & Lucalle & Lucaillen \\
\hline Akkusatiivi & Lucan & Lucas & Lucan\&Lucasta & Lucat\&Lucaita \\
\hline Vokatiivi & Luca & Lucae & Luca $[!]^{26}$ & Lucat \\
\hline Ablatiivi & & Lucaldal & $\begin{array}{l}\text { Lucaildal } \\
\text { Lucaista/jne. } \\
\text { Lucasal } \\
\text { Lucalla }\end{array}$ \\
\hline
\end{tabular}

Deklinaatiojärjestelmä ei itsessään riitä suomen nominien vartalonvaihtelujen kattavaksi kuvaamiseksi. Yleisiä äännevaihteluita tai paremminkin "kirjainten ja tavujen vaihtelevaa käyttöä" (litterarum et syllabarum variae usurpationes) on kuvattu sekä Petraeuksen että Martiniuksen kieliopin alussa taulukkomuodossa, varsinaisen kieliopin ulkopuolella. Taulukon ja deklinaatioiden paradigmat yhdistämällä saattoi taivuttaa jo melko suurta osaa suomen nomineista. Järjestelmällistä astevaihtelun tai vokaalisoinnun kuvausta taulukosta ei kuitenkaan löydä (Wiik 1989: 24-40; vrt. myös Bentlin 2013: 114-116).

Rudimenta (ks. Lauerma \& Randén toim. 2012: [79-80]) ei käsittele deklinaatioita. Siinä todetaan kuitenkin, että vaikka nominatiivien päätteet vaihtelevatkin, muissa sijapäätteissä on "jossain määrin säännönmukaisuutta" (esse quandam analogiam), jonka perusteella kaikki loput muodot taipuvat. Myöskään Rudimentasta on turha etsiä järjestelmällistä erottelua vartaloon ja päätteisiin.

Vhaelin deklinaatiot (ks. taulukkoa 6) poikkeavat edeltäjistään sikäli, että teemavokaalien sijaan nominit on jaettu vokaaliin päättyviin, -nen-loppuisiin samatavuisiin ja $n$-, $t$ - ja $s$-loppuisiin eritavuisiin sanoihin. Tavumäärän käyttäminen apuna on tuttua

24. Esimerkkisana Lucas on tässä otettu vastineeksi Martiniukselle latinan 1. deklinaation demonstroimiseksi.

25. Martiniuksen (1689: [20]) esimerkkisana ensimmäisestä deklinaatiosta, jonka hän taivuttaa monikossa huolimatta siitä, että se on erisnimi.

26. Martinius antaa ainoastaan esimerkkisanan Lucas taivuttaessaan erillisen, nominatiivista poikkeavan vokatiivi- eli puhuttelumuodon latinan mallin mukaan. Muuten suomen vokatiivi on aina samanmuotoinen nominatiivin kanssa. 
myös latinan kolmannesta deklinaatiosta. Kuten Wiik (1989: 102-104) toteaa, Vhaelin mallia voidaan pitää askelena kohti itsenäistä, "fennististä" tarkastelutapaa, jossa yhtä sijaa vastaa yksi sijapääte ja deklinaatiosäännöt on määritelty nominatiivista käsin.

Taulukko 6.

Suomen deklinaatiot Vhaelin mukaan (1733: 14-18).

\begin{tabular}{l|l|l} 
Deklinaatio & Sananloppu & Muita ehtoja \\
\hline I & vokaali $($ kala $)$ & \\
\hline II & nen (ihminen) & $\begin{array}{l}\text { tavumäärä on vakio } \\
\text { nom. > gen. }\end{array}$ \\
\hline III & $n, s, t($ siemen $)$ & $\begin{array}{l}\text { tavumäärä vaihtuu } \\
\text { nom. }>\text { gen. }\end{array}$ \\
\hline
\end{tabular}

Deklinaatioita seuraa vielä joukko nykytermein vartalonvaihteluun liittyviä fonologisia sääntöjä, joista osan Petraeus ja Martinius esittävät irtolehdellä ennen varsinaista etymologia-osaa. Lisäksi annetaan ohjeita sijojen omistusliitteellisestä muodostamisesta. Taivutusvartalon kannalta keskeinen "kirjainten vaihtelu" on esitetty ortografian alaisuudessa. (Vhael 1733: [9-11].) Jakamalla vokaalit luokkiin maiores ( $a, o, u)$, minores $(\ddot{a}, \ddot{o}, y)$ ja mediae (e, $i)$ Vhael ennakoi jo vokaalisoinnun eksplisiittistä määrittelyä. Muuten äännevaihtelujen esitys ei perustavalla tavalla eroa Petraeuksesta ja Martiniuksesta, eikä esimerkksi astevaihtelua ilmiönä eroteta muista vartalonvaihteluista (vrt. Bentlin 2013: 116).

\subsection{Komparaatio}

Vertailuasteiden käsittelyssä varhaisen uuden ajan kieliopeissa on keskeisiä eroja, jotka juontuvat myöhäisantiikista asti (ks. taulukkoa 7). Teoksessaan Institutiones Priscianus (GL 2: 59-60, 83-84) ei mainitse komparaatiota omana aksidenssinaan vaan ainoastaan specieksen alaisuudessa. Toisaalta hän liittää vertailuasteet adjektiiveihin eli "adjektiivisiin nomineihin" (nominibus adiectiuis). Brassicanus ja Heinrichmann yhdistävät vertailuasteet adjektiiveihin kuten Priscianus, mutta erottavat ne omaksi aksidenssikseen kuten Donatus.

Donatuksella ei esiinny adjektiivi-käsitettä, joten komparaatio rajoittuu hänellä "laadullisiin ja määrällisiin appellatiiveihin". Tämä määritelmä löytyy vielä Perottilta ja Melanchthonilta, vaikka he muuten puhuvatkin adjektiiveista. Melanchthonin kieliopin eri laitokset käsittelevät myös komparaatiota eri tavoin. Alkuperäisessä, vuoden 1526 kieliopissa se esiteltiin nominien ensimmäisenä aksidenssina, sillä käsite 'nomini' kattaa sekä substantiivit että adjektiivit. Vuoden 1661 [1634] "Melanchthon" sekä Chytraeus (1621: 51-56) käsittelevät komparaation jo yhtenä adjektiivien erityispiirteenä.

Petraeus ei komparaationkaan kohdalla anna määrittelyä, vaan ainoastaan esimerkkejä muutaman adjektiivin vertailumuodoista, kuten epäsäännöllisesti komparoituvista sanoista hyvä ja pitkä. Sen sijaan Martiniuksen (1689: 32-33) mukaan ver- 
tailu koskee niitä adjektiiveja, jotka usus eli kielen käyttö sellaisiksi todistaa. Vhaelilla vertailu koskee yksiselitteisesti adjektiiveja. Myös Martinius mainitsee poikkeavat komparaatiomuodot hyvä, parempi, paras ja pitkä, pidempi, pisin. Vhael on lisännyt näihin vielä adjektiivit paljo ja moni (komparoimaton).

\section{Taulukko 7.}

Komparaation määritelmä ja komparoitava sanaluokka. NOM = Komparaatio koskee nomineja, joiden "merkitystä voi suurentaa tai pienentää". APP = Komparaatio koskee appellatiiveja, jotka ilmaisevat määrää tai laatua. ADJ- = Komparaatio koskee niitä adjektiiveja, joiden vertailumuodot ovat vakiintuneita. $A D J+=$ Komparaatio koskee adjektiiveja.

\begin{tabular}{|c|c|c|}
\hline Grammaatikko & Määritelmä: mitä sanoja komparaatio koskee & Sanaluokka \\
\hline $\begin{array}{l}\text { Donatus } \\
\text { (Holtz 1981: 586) }\end{array}$ & $\begin{array}{l}\text { appellativa dumtaxat qualitatem aut quantitatem } \\
\text { significantia }\end{array}$ & APP \\
\hline Perotti (1477: a3v) & $\begin{array}{l}\text { appellativa dumtaxat qualitatem aut quantitatem } \\
\text { significantia }\end{array}$ & APP \\
\hline $\begin{array}{l}\text { Heinrichmann } \\
\left(1506: b_{3}\right)\end{array}$ & $\begin{array}{l}\text { nomen adiectivum significans accidens quod incre- } \\
\text { mentum uel diminutionem suscipere potest }\end{array}$ & ADJ- \\
\hline $\begin{array}{l}\text { Brassicanus } \\
(1508: \text { b3) }\end{array}$ & $\begin{array}{l}\text { Adiectiva [nomina] solum quae augendi vel diminu- } \\
\text { endi significationem habent. Nec illa quidem omnia, } \\
\text { sed ea solum quę apud idoneos scriptores compilata } \\
\text { leguntur. }\end{array}$ & ADJ- \\
\hline $\begin{array}{l}\text { Melanchthon } \\
(1527: \text { a4v) }\end{array}$ & $\begin{array}{l}\text { Comparantur nomina, quorum significatio augeri } \\
\text { minuive potest. }\end{array}$ & NOM \\
\hline Bonnus (1603: a3v) & Positivus, Prima vox Adiectivi est. & ADJ+ \\
\hline $\begin{array}{l}\text { Chytraeus } \\
(1621: 53)\end{array}$ & $\begin{array}{l}\text { Comparantur Adjectiva, quorum significatio augeri } \\
\text { vel minui potest, \& quae usus eruditorum probat. }\end{array}$ & ADJ- \\
\hline $\begin{array}{l}\text { "Melanchthon" } \\
\text { (1661 [1634]: 19-20) }\end{array}$ & $\begin{array}{l}\text { Comparatio est variatio Adjectivi cujuscunque Gene- } \\
\text { ris per gradus. Quae Adjectiva comparantur? Quo- } \\
\text { rum significatio augeri vel minui potest; si modo illo- } \\
\text { rum Comparationem usus approbavit. }\end{array}$ & ADJ- \\
\hline $\begin{array}{l}\text { Martinius } \\
\text { (1689: }[32])\end{array}$ & $\begin{array}{l}\text { Comparatio Nominum Adjectivorum fit, quae usus } \\
\text { probat. }\end{array}$ & ADJ- \\
\hline $\begin{array}{l}\text { Rudimenta } \\
\text { (Lauerma \& Randén } \\
\text { toim. 2012: [80-81]) }\end{array}$ & $\begin{array}{l}\text { Gradus comparationis Nominum Adjektivorum, sunt } \\
\text { quatuor: Positivus, Comparativus, Superlativus et } \\
\text { plus q[vam] Superlativus. }\end{array}$ & $\mathrm{ADJ}+$ \\
\hline Vhael (1733: [37]) & Comparantur adjectiva per tres gradus. & $\mathrm{ADJ}+$ \\
\hline
\end{tabular}

Taulukko 8 (ks. seur. s.) havainnollistaa, miten suomen varhaisissa kieliopeissa on kuvattu komparaatiomuotojen muodostamista. Muodostuksen selventäminen on edellyttänyt Martiniukselta ja Vhaelilta muutakin kuin latinan mallin kopiointia, vaikka heidän kuvauksensa perustuu kirjainten vaihteluun genetiivi- tai nominatiivimuodosta käsin kuten deklinaatioissa (ks. taulukkoa 8). Rudimentassa on esitetty myös neljäs vertailuaste, plus quam superlativus, jolle ei Lauerman mukaan (2012: 94) löydy esikuvaa. Se esiintyy tosin myöhemmin, vuonna 1720 ilmestyneessä Agostino Maria de Monten teoksessa Latium restitutum, seu Latina lingua in veterem restituta splendorem 
(1720: 1752). Koska on epätodennäköistä, että suomen varhaiskieliopit olisivat olleet tämän italialaisen kielioppiteoksen esikuvana, voidaan perustellusti olettaa molempien nojanneen johonkin varhaisempaan yhteiseen esikuvaan.

Taulukko 8.

Vertailuasteiden muodostaminen.

\begin{tabular}{|c|c|c|c|}
\hline & Lähtömuoto & Komparatiivi & Superlatiivi \\
\hline Latinan kieliopit & $\begin{array}{l}\text { positiivin vartalo }+i \\
\text { laet. } i\end{array}$ & $\begin{array}{l}\text { or } \\
\text { laeti.or }\end{array}$ & $\begin{array}{l}\text { ssimus } \\
\text { laeti.ssimus }\end{array}$ \\
\hline $\begin{array}{l}\text { Martinius } \\
\text { (1689: 32-33) }\end{array}$ & $\begin{array}{l}\text { positiivin genetiivi } \\
\text { ahtan }\end{array}$ & $\begin{array}{l}(n \rightarrow m) b i \\
\text { ahtam.bi }\end{array}$ & $\begin{array}{l}\text { /i/ viimeisen ja } \\
\text { viimeistä edellisen } \\
\text { kirjaimen välissä } \\
\text { ahta.i.n }\end{array}$ \\
\hline $\begin{array}{l}\text { Vhael } \\
\text { (1733: 37-38) }\end{array}$ & $\begin{array}{l}\text { ei yhteistä lähtö- } \\
\text { muotoa }\end{array}$ & $\begin{array}{l}\text { 1) vokaaliloppuiset: } \\
\text { positiivin } \\
\text { nominatiivista } \\
(a / \ddot{a} \rightarrow e) m p i \\
\text { matala } \rightarrow \\
\text { matalempi } \\
\text { 2) kons.-loppuiset: } \\
\text { positiivin } \\
\text { genetiivistä } \\
(n \rightarrow m / i \rightarrow e) \\
m p i \\
\text { caunis } \rightarrow \\
\text { caunehempi } \\
\text { iloinen } \rightarrow \text { iloisempi }\end{array}$ & $\begin{array}{l}\text { positiivin } \\
\text { genetiivin } \\
\text { viimeinen vokaali } \\
\text { muuttuu } i \text { :ksi } \\
\text { matalan } \rightarrow \text { matal.i.n }\end{array}$ \\
\hline
\end{tabular}

Silmiinpistävää Petraeuksen kieliopissa on, että kappale III De Accidentibus Nominis ("nominien aksidensseista") päättyy ennen komparaatiota. Komparaatio muodostaa Petraeuksella oman kappaleensa, samoin kuin figura, species sekä paradigmaja anomaliataulukot. Yleensä komparaatio luettiin nominin aksidensseihin. Vihonen pohtii (1978: 85-86), olisiko Petraeus kenties halunnut tietoisesti ilmaista genuksen, numeruksen, kaasuksen ja deklinaation poikkeavan muista aksidensseista, muttei keksi jaolle hyvää syytä. Käsittelemistämme 1500-luvun kieliopeista puuttuu vielä numeroitu kappalejako, ja ne jakautuvat ainoastaan otsakkeiden perusteella osiin, sanaluokkiin sekä näiden alaisiin aksidensseihin; Chytraeuksen ja vuoden 1661 ramistisen "Melanchthonin" kappalejako pyrkii hahmottamaan käsiteltävät asiat sopivan mittaisiin jaksoihin jakamatta asioita eri hierarkiatasoille. Todennäköisesti myös Petraeus on pyrkinyt suppeassa esityksessään suunnilleen samanmittaisiin kappaleisiin.

\subsection{Figura}

Donatuksen mukaan nominit ovat hahmoltaan yksinkertaisia (simplicia) tai yhdistettyjä (composita). Hän esittää, että on olemassa neljänlaisia yhdyssanoja riippuen siitä, ovatko yhdysosat ehjiä (integer) eli itsenäisiä vai rikkonaisia (corruptus) eli epä- 
itsenäisiä. Donatuksen esitys nojaa yksinomaan esimerkkisanoihin. Samoin on laita suurimmassa osassa tarkasteltuja kielioppeja. Priscianuksella on myös yhdyssanajohdoksille oma kategoriansa (decompositus; GL 2: 177). Osa humanistikieliopeista toteaa pelkästään, että on yhdistämättömiä ja yhdyssanoja; osa mainitsee Priscianuksen decomposituksen, osa ehjät ja rikkonaiset yhdysosat. Heinrichmannin ja Bonnuksen esitykset ovat suppeimmat. Niissä todetaan vain yhdistämättömien ja yhdistettyjen nominien olemassaolo. Käsite decompositus esiintyy vertailluissa kieliopeissa viimeisen kerran Melanchthonilla (1527). Vuoden 1661 [1634] "Melanchthonissa", Chytraeuksella ja Martiniuksella on edeltäjiinsä nähden uutena luettelo niistä sanaluokista, joita yhdistämällä nomineja voi muodostaa. Chytraeus on lisäksi käynyt läpi yhdyssanojen osien taipumista: joitakin vakiintuneita nominaalilausekkeita saatettiin tuon ajan latinassa kirjoittaa yhteen, esimerkiksi respublica tai parsorationis, jolloin kuitenkin myös ensimmäinen osa taipui.

Suomen kieliopeissa on simplex- ja compositum-kategoriat muutamine esimerkkisanoineen. Petraeus ja Martinius huomauttavat tässä myös - $t O(i) n$-loppuisista sanoista eli karitatiivijohdoksista. Ne on esitetty käännösvastineina in-privatiivisanoille, joita on paljon latinan kielioppien figura-luvun esimerkkisanoina. Tämä johtuu siitä, että niissä in-privatiiviprefiksi, samoin kuin prepositioprefiksit, on luettu prepositioihin; nykylukija pitäisi niitä ennemmin johtimina kuin yhdysosina. Vhael (1733: [44]) onkin esittänyt karitatiiviadjektiivit privativa- eli negativa-nimisinä specieksen, "johtamisen" alaisuudessa. Näiden sanojen käsittelyä seuraavat esimerkkiparadigmat yhdyssanoista rucouskirja, käsikiria, kiittämätöin, kelwotoin, jotka havainnollistavat taivutuksen rajoittumista sanan loppuun. Vhaelin (1733: [39]) huomautus, ettei suomessa ole kovinkaan paljon (non ita multum) yhdyssanoja, kun taas johtamista käytetään runsaammin, saattaa vaikuttaa nykylukijasta yllättävältä.

\subsection{Species}

Species-kategorian juuret ovat kahtalaiset. Sana merkitsee yleisesti lajia tai alalajia, ja Donatuksen laajemmassa Ars maiorissa se esiintyy muun muassa qualitaksen alakategoriana, kun taas Priscianuksella species on oma aksidenssinsa, jonka alaisuudessa on esimerkiksi komparaatio (GL 2: 57). Donatuksella ja Priscianuksella sekä vielä Perottilla species liittyy myös sanojen jaotteluun puhtaasti semanttisin perustein, kun taas 1500- ja 1600-luvun kieliopeissa sen tehtävänä on esitellä yleisimmät johdostyypit (Luhtala 2005: 42). Numeraalit käsitellään vielä 1600-luvullakin useimmiten osana nominien speciestä, kuten taulukosta 9 käy ilmi.

Petraeuksen ja Martiniuksen johdostyypit heijastelevat suoraan latinan kielioppia: molemmat esittelevät suomen johdostyyppeinä possessiivit (llinen-päätteiset sanat), kansojen nimitykset, diminutiivit, denominatiivit, verbaalit ja numeraalit, jotka on vielä jaoteltu kardinaali-, ordinaali-, distributiivi- ja multiplikatiivilukuihin. Vhaelin esitys on huomattavasti edeltäjiään monipuolisempi ja itsenäisempi. Siinä suomen eri johtimet on otettu jaottelukriteeriksi latinasta perittyjen semanttisten kategorioiden rinnalle. Rudimentassa ei käsitellä figuraa tai speciestä (sanahahmoa tai sananmuodostusta). 
Taulukko 9.

Species.

\begin{tabular}{|c|c|}
\hline Kielioppi & Käsitellyt lajit \\
\hline $\begin{array}{l}\text { Donatus Ars maior (Holtz 1981: 614- } \\
\text { 615), Perotti (1477: a2v-a3v) }\end{array}$ & $\begin{array}{l}\text { incorporalia, corporalia, primae positionis, } \\
\text { derivativa, diminutiva jne. (yht. yli } 20 \text { lajia) }\end{array}$ \\
\hline $\begin{array}{l}\text { Brassicanus (1508: b1-b2) } \\
\text { Melanchthon (1527: f2r) } \\
\text { "Melanchthon" (1661 [1634]: 11, 100- } \\
\text { 1111 }{ }^{28} \text {, Chytraeus (1621: 58-60), } \\
\text { Petraeus (1649: 20-21), } \\
\text { Martinius (1689: 36-38) }\end{array}$ & $\begin{array}{l}\text { patronyymit ja kansojen nimet, possessiivit, } \\
\text { diminutiivit, denominatiivit numeraalit, verbaalit }\end{array}$ \\
\hline Vhael (1733: 39-49) & $\begin{array}{l}\text { A. derivativa nominalia llinen-adjektiivit, } \\
\quad \text { diminutiivit, adjektiivit yleisesti, kansojen } \\
\text { nimet, privatiivit jne. } \\
\text { B. derivativa verbalia -nen, -ma, -ja/jä, -os jne. } \\
\text { C. adverbialia } \\
\text { D. numeralia }\end{array}$ \\
\hline
\end{tabular}

Vihosen (1978: 104) maininta siitä, että saksan vanhimman kieliopin tekijä Albert Ölinger olisi erottanut numeraalit "jo niin varhain kuin 1578" ja että 1600-luvun grammaatikoilla olisi ollut harkittavanaan uudistus pitää lukusanoja omana sanaluokkanaan, perustuvat nekin lähdeongelmaan: Vihosella ei ollut käytössään Perottin kielioppia vuodelta 1473, Heinrichmannin kielioppia vuodelta 1506 tai Melanchthonin alkuperäistä kielioppia, joissa numeraalit mainitaan omana ryhmänään. ${ }^{29}$

\subsection{Status}

Status (asema, omisteisuus) on ainoa muotokategoria näissä varhaisissa suomen kieliopeissa, jota ei ole omaksuttu latinasta. Sen esikuva lienee ollut heprean kielioppi. Petraeus ei vielä käsittele omistusliitteitä, mutta kieliopin lopussa, luvussa Resolutio, joka on Raamatun tekstikappaleiden kieliopillinen kommentaari, hän analysoi teidän päällen prepositioksi, jossa on tuotu ilmi toinen persoona (1649: 84). Martinius käsittelee omistusliitteitä parissa lauseessa observationes-kohdassa, joka sisältää nomineihin liittyviä irrallisia huomioita varsinaisten aksidenssien lisäksi. Hän toteaa substantiivin taipuvan adjektiivisen omistuspronominin jäljessä (esimerkkinä minun kirjani). Ainoastaan Vhaelilla status on oma aksidenssinsa (1733: [4-5], [13]). Vhaelin jälkeen tämä muotokategoria esiintyi Henrik Gananderin lapin kieliopissa Grammatica lapponica (1743).

27. Perotti ja Donatus esittävät specieksen qualitaksen alaisuudessa.

28. Johdostyypit on esitetty omana kappaleenaan De derivatis. Jako kantasanoihin ja johdoksiin on esitetty kaikkia sanaluokkia koskevana.

29. Käsite numeraali esiintyy omana luokkanaan jo esimerkiksi 1400 -luvun lanuassa ja sitäkin ennen Priscianuksella (GL 3: 88), mutta vain adverbien yhteydessä. 


\section{Päätelmiä}

Olemme tässä kirjoituksessa tarkastelleet suomen varhaiskielioppien nominikategorian kuvausta ja vertailleet sitä eurooppalaisiin latinan kielioppien kuvauksiin. Olemme todenneet, että se noudattelee latinan kielioppien eurooppalaista perinnettä. On helppo yhtyä Vihosen (1978: 77-104) näkemykseen Chytraeuksesta ja Tideruksesta suomen varhaiskielioppien keskeisinä esikuvina, mutta - kuten Vihonenkin toteaa on huomattava, että muitakin vaikutteita on ollut. Lisäksi on otettava huomioon, että Chytraeuksen nimissä kulkeneen kieliopin varhaisia painoksia ei ole säilynyt, vaan sekä hänen että Bonnuksen kielioppien nykypäiviin säilyneet laitokset ovat muiden toimittamia.

Keskeisin täsmennystä vaativa seikka, joka tässä tarkastelussa tuli esiin, on se, että 1600-luvulla painetuista, Melanchthonin nimissä kulkevista kieliopeista ei tule tehdä humanistikielioppeja koskevia johtopäätöksiä. Ne edustavat eri aikakautta ja ovat saaneet vaikutteensa ja useat erottavat piirteensä Petrus Ramuksen koulukunnan kielenkuvauksista. Esimerkkinä voidaan mainita nominien jaottelu sekä niiden aksidenssien esittely. Mitä useampaan varhaisen uuden ajan kielioppiin perehtyy, sen selvemmin huomaa, että käsitteet humanistikielioppi tai reformaatiokielioppi eivät ole yksiselitteisiä. Kielioppien keskinäiset vaikutussuhteet ja painotukset ovat moninaiset. Niiden kehitys ei aina ole suoraviivaista, vaan samanaikaisesti on ilmestynyt niin perinteisiä kuin "moderneja" oppikirjoja. Käsitteet, määritelmät ja jaottelut ilmaantuvat joskus uusina ja katoavat sitten vuosikymmeniksi tai -sadoiksi palatakseen taas kielenkuvauksiin. Uudistukset eivät liioin ole aina vieneet kohti parempaa kielenkuvausta, vaan joskus tuloksena on ollut kooste, jossa on rinnakkain aineksia eri lähteistä.

Vihosen tutkimuksen ongelmakohta selittyy rajoituksista, jotka eivät olleet hänen vallassaan: hänen käyttämänsä "humanistikieliopit" ovat kaikki 160o-luvulta. Tämä on sikäli puolustettavissa, että nämä teokset ovat luultavasti olleet juuri niitä, joita Suomen varhaiset grammaatikot ovat pitäneet käsissään. Silloin kun selostetaan humanistikielioppien rakennetta, määritelmiä tai kannanottoja, ei näitä 160o-luvun teoksia voida kuitenkaan pitää asianmukaisina lähteinä. Ne saattavat pahimmassa tapauksessa jopa johtaa väärään käsitykseen vaikkapa sanaluokkakäsitysten tai syntaksin historiasta.

Vaikka kieliopit näyttävät säilyttäneen runsaasti ominaisuuksia aina antiikista nykypäivään, on grammatikografiassa aika ajoin tapahtunut paradigmavaihdoksia, joista osa on jättänyt pysyvät jäljet ja osa taas on osoittautunut ohimeneviksi ilmiöiksi. 150oja 160o-lukujen vaihteessa filosofian rationalistinen suuntaus vaikutti myös näkemyksiin kielestä, kieliopin tavotteista ja sen esittämisperiaatteista. Vaikuttaa siltä, että tämä uudenlainen filosofinen orientaatio ei ole koskettanut suomen varhaisia kielioppeja, sillä niissä ei ole havaittavissa universaalikieliopin tunnusmerkkejä.

Suomalaisten kirjastojen kokoelmissa on vain harvoja eurooppalaisia kielioppiteoksia, jotka olisi kirjoitettu ennen 1500-luvun puoltaväliä, mutta varhaisia kielioppeja, aina keskiajalta lähtien, on nykyisin saatavana verkossa digitalisoituina. Esimerkiksi Saksan, Englannin ja Ranskan kirjastot ovat päättäneet luovuttaa kirja- 
aarteensa digitalisoituina koko maailman käyttöön. Myös antiikin kielioppeja on editoitu verkkojulkaisuiksi, joissa on käyttökelpoiset hakutoiminnot (CGL). Digitalisointi on tuonut ulottuvillemme aivan uudet mahdollisuudet tutkia varhaisia lähteitä. Tämä ei voi olla heijastumatta siihen, miten arvioimme omaa tieteenhistoriaamme.

Uudet mahdollisuudet käyttää lähteitä avaavat kiintoisia näkymiä lisätutkimukselle. Olisikin antoisaa tarkastella lähemmin vähemmän tutkittuja suomen varhaiskielioppeja, kuten Bartholdus Vhaelin teosta, tai kartoittaa hänen käyttämiään lähteitä. Myös verbiopin vaiheiden tai syntaktisten käsitteiden kulkeutumisen selvittelyssä riittää työsarkaa. Laajempi aineisto, joka kattaisi enemmän myös varsinaisia humanistikielioppeja, voisi valaista grammatikografian vaiheita tarkemmin.

\section{Lähteet}

\section{Aineistolähteet}

Albertus, Laurentius 1573: Teutsch Grammatick oder SprachKunst. Augustae Vindelicorum: Manger.

Anon. n. 1478: Ianua. [Venedig]. Urn:nbn:de:bvb:12-bsbooo35885-4.

Anon. [Wert, Wilhelm] n. 1485: Compendium octo partium orationis. [Basel]. Urn:nbn:de:bvb:12-bsbooo34206-2.

Anon. [Wert, Wilhelm] 1491: Exercitium puerorum grammaticale per dietas distributum. Hagenau: Gran. Urn:nbn:de:bvb:12-bsbooo34340-6.

Anon. [Chytraeus, Nathan] 1646: Donatus Sive Progymnasmata Grammaticae Latinae Pro Classe Tertia Scholae Rostochianae. [Rostock]: Wilde. http://purl.uni-rostock.de/rosdok/ ppn728232669 (27.9.2017).

Arnauld, Antoine - Lancelot, Claude 1660: Grammaire Générale et raisonnée. Paris: Pierre le Petit.

Arnoldi, Bartholomeus 1508: Figure Donati. Liptzk: Wolfgangus Monacensis.

Bonifatius ks. Gebauer \& Löfstedt (toim.).

Bonnus, Hermann 1603: Elementa partium orationis. Lubecae: Albertus. http://diglib.hab.de/ drucke/p-842-8f-helmst-1s/start.htm (27.9.2017).

Brassicanus, Johannes 1508: Institutiones Grammatice Joannis Brassicani. Argentinae: Johann Prüss.

Charisius ks. Barwick 1925.

Chytraeus, Nathan 1582: Nomenclator Latino-saxonicus. Rostock: Myliander.

- 1621: Grammatica Latina. Conscripta Olim a Nathane Chytraeo. Lubecae: Iauchius. http:// purl.uni-rostock.de/rosdok/ppn770615872 (27.9.2017).

- 1667: Grammatica Latina. In Usum Scholae Lubecensis, Rostochi[i]: Richelius. http://diglib. hab.de/drucke/xb-7646-1s/start.htm (29.9.2017).

Despauterius, Johannes 1515: Syntaxis Joa[n]nis Despauterij. Argentorati: Schurer. Urn:nbn:de:bvb:12-bsboooo5605-7.

- 1518: Rudimenta Ioannis Despauterii de octo partibus orationis. Lipsiae, Schumann. http:// www.mdz-nbn-resolving.de/urn/resolver.pl?urn=urn:nbn:de:bvb:12-bsb10163959-1.

- 1522: Grammaticae institvtionis pars prima. St.Coloniam: Cervicornus. http://nbn-resolving.de/urn:nbn:de:gbv:3:1-473113 de:gbv:3:1-473113. 
Donatus ks. Holtz, Louis (toim.).

Ganander, Henrik 1743: Grammatica lapponica. Holmiae: Laurentius Salvii.

Guarino GuARINi 1471: Regulae grammaticales. [Venetiis]. Urn:nbn:de:bvb:12-bsbooo35809-8.

Heinrichmann, Ja ков 1506: Grammaticae institutiones. Phorca: Thomas Anshelm.

Hundt, Magnus 1487: Expositio Donati. Köln: Heinrich Quentell.

ISK = Hakulinen, Auli - Vilkuna, Maria - Korhonen, Rittta - Koivisto, Vesa - Heinonen, Tarja Rittta - Alho, Irja 2004: Iso suomen kielioppi. Suomalaisen Kirjallisuuden Seuran Toimituksia 950. Helsinki: Suomalaisen Kirjallisuuden Seura. http:// scripta.kotus.fi/visk. URN:ISBN:978-952-5446-35-7.

JuDÉN, ЈАСОВ 1818: Försök till Utredande af Finska språkets Grammatik. Wiborg: Anders Cederwaller.

Lily, William 1552: A shorte introduction to grammar. Londini: Reginald Wolf.

Linacre, Thomas 1527 [1524]: De emendata structura Latini sermonis. Parisiis: Robert Stephanus.

Martinius, Mat thias 1968 [1689]: Hodegus Finnicus, Eller Finsk Wägwijsare. Helsinki: Suomalaisen Kirjallisuuden Seura.

Melanchtinon, Philip 1526: Elementa Latinae Grammatices. Norembergae: Petreius.

— 1527: Syntaxis. Norembergae: Petreius. Urn:nbn:de:bvb:12-bsb11280832-o.

— 1661 [1634]: Grammatica Latina. Wittembergae: Seelfisch. Urn:nbn:de:gbv:3:1-42873.

Monte, Agostino Maria De 1720: Latium restitutum, seu Latina lingua in veterem restituta splendorum. Osa 4. Roma: Antonius de Rubeis.

Perotti, Niccolò [1476]: Rudimenta grammatices, [Venedig]. Urn:nbn:de:bvb:12-bsbooo57901-2.

Petraeus, Eskil 1968 [1649]: Linguae Finnicae brevis institutio. Helsinki: Suomalaisen Kirjallisuuden Seura.

Priscianus Caesariensis: Institutio de nomine et pronomine et verbo. GL 3 s. 443-456, Leipzig: Teubner.

Priscianus Caesariensis: Prisciani grammatici Caesariensis institutionum grammaticarum libri XVIII [Institutiones grammaticae]. GL 2-3 s. 1-137. Leipzig: Teubner.

Priscianus Caesariensis: Partitiones duodecim. GL 3 s. 459-515. Leipzig: Teubner.

Ramus, Petrus 1559: Grammaticae libri quatuor. Paris: Andreas Wechelus.

Sanctius, Francisus 1661 [1587]: Minerva, seu de causis linguae latinae. Amstelodami: Pluymer.

Scaliger, Julius Caesar 1540: De causis linguae Latinae libri tredecim. Lugduni: Gryphius. SMARAgdus ks. Löfstedt, Holtz \& Kibre (toim.) 1986.

Strahlmann, Johann 1816: Finnische Sprachlehre für Finnen und Nicht-Finnen. St. Petersburg: M.C. Ibersen. Urn:nbn:de:bvb:12-bsb10589121-6.

TAtvinus ks. Marco de (toim.) 1968.

Tiderus, Arvid 1731 [1640]: Grammatica latina. Holmia.

Vhael, Bartholdus 1968 [1733]: Grammatica Fennica. Helsinki: Suomalaisen Kirjallisuuden Seura.

Villa Dei, Alexander: Doctrinale ks. Reichling.

Vossius, Gerard 1635: Gerardi Ioannis Vossii De Arte Grammatica Libri Septem. Amsterdami: Blaeu.

Ölinger, Albert 1573: Underricht der hoch teutschen Spraach. Grammatica seu institutio verae Germanicae linguae. Argentorati: Wyriot. 


\section{Kirjallisuus}

BARWICK, Carolus 1925: Charisii Artis grammatici libri V. Bibliotheca scriptorum Graecorum et Romanorum Teubneriana. Lipsiae: Teubner.

Bentlin, Mıкко 2013: Zur linguistischen Terminologie in finnischen Grammatiken vor 1900. Fallstudie Stufenwechsel und Vokalharmonie. - Marja Järventausta \& Marko Pantermöller (toim.), Finnische Sprache. Literatur und Kultur im deutschsprachigen Raum s. 113-129. Veröffentlichungen der Societas Uralo-Altaica 86. Wiesbaden: Harrassowitz.

Cherubim, Dieter 1973: Hermann Paul und die moderne Linguistik. Zur Studienausgabe von H. Pauls 'Prinzipien der Sprachgeschichte.' - Zeitschrift für Dialektologie und Linguistik 40 s. $310-322$.

$\mathrm{CGL}=$ Corpus grammatikorum latinorum. http://kaali.linguist.jussieu.fr/CGL/text.jsp (22.9.2017).

EEBO = Early English Books Online. https://eebo.chadwyck.com/home (27.9.2017).

Gebauer, George John - Löfsted, Bengt (toim.) 1980: Bonifatii (Vynfreth) Ars grammatica. [Accedit Ars metrica]. Corpus christianorum. 133 B. Turnholt: Brepols.

GL $=$ KeIL, HeINRICH (toim.) 1855-1880: Grammatici Latini ex recensione H. Keilii. Niteet 1-8. Lipsiae: Teubner.

Glǘck, Helmut 2002: Die Volkssprachen als Lerngegenstand im Mittelalter und in der frühen Neuzeit. Berlin: Walter De Gruyter.

Henkel, Nicolaus 1988: Deutsche Übersetzungen lateinischer Schultexte. München: Akademie Verlag.

Henriksen, Carol - Hovdhaugen, Even - Karlsson, Fred - Sigurd, Bengt (toim.) 2000: The history of linguistics in the Nordic countries. Societas Scientarum Fennica. Jyväskylä: Gummerus.

Holtz, Louis (toim.) 1981: Donat et la tradition de l'enseignement grammatical. Étude sur l'Ars Donati et sa diffusion (IVe - IXe siècle) et édition critique. Paris: Centre national de la recherche scientifique.

HSK = Handbücher zur Sprach- und Kommunikationswissenschaft. Toimittaneet Sylvain Auroux, Gerold Ungeheuer, Armin Burkhard ym. Handbooks of Linguistics and Communication Science 18/1. Berlin: Walter De Gruyter 2008.

HÄKKInEN, KAISA 200oa: Early grammatical descriptions of Finno-Ugric. - Sylvain Auroux (toim.), History of the language sciences 1 s. 806-814. Berlin: Walter de Gruyter.

— 20oob: Suomen kirjakielen sijajärjestelmän vakiintuminen 180o-luvulla. - Matti Punttila, Raimo Jussila \& Helena Suni (toim.), Pipliakielestä kirjakieleksi s. 171-201. Helsinki: Kotimaisten kielten tutkimuskeskus. 2002: Suomalaisen oppikirjan vaiheita. Helsinki: Suomen tietokirjailijat ry.

Kärnä, Aino - Luhtala, Anneli (tekeillä): Handbuch frühneuzeitlicher Grammatiken. Editiones Electronicae Guelferbytanae ZZ. Wolfenbüttel: Herzog August Bibliothek.

Lauerma, Petri 2012: Rudimentan tausta ja luonne. - Petri Lauerma \& Suvi Randén (toim.), Rudimenta linguae Finnicae breviter delineata. Suomen kielen varhaiskielioppi ja sen tausta s. 93-98. Helsinki: Suomalaisen Kirjallisuuden Seura.

Lauerma, Petri - Randén, Suvi (toim.) 2012: Rudimenta linguae Finnicae breviter delineata. Suomen kielen varhaiskielioppi ja sen tausta. Helsinki: Suomalaisen Kirjallisuuden Seura.

LAw, Vivien 1982: The insular Latin grammarians. Woodbridge: Boydell Press.

- 1997: Grammar and grammarians in the early Middle Ages. London: Longman. 
2003: The history of linguistics in Europe. From Plato to 1600. Cambridge: Cambridge University Press.

Luhtala, Anneli 2005: Grammar and philosophy in Late Antiquity. A study of Priscian's sources. Amsterdam: John Benjamins.

Löfstedt, Bengt - Holtz, Louis - Kibre, Adele (toim.) 1986: Smaragdus Liber in Partibus Donatii. Corpus Christianorum. Continuatio Mediaeualis LXVII. Turnholti: Brepols.

Marco, Maria De (toim.) 1968: Ars Tatvini. Corpus Christianorum. Series Latina 133. Turnholti: Brepols.

RANDÉN, Suvi 2012: Alkuteksti ja suomennos. - Petri Lauerma \& Suvi Ránden (toim.), Rudimenta linguae Finnicae breviter delineata. Suomen kielen varhaiskielioppi ja sen tausta s. 49-92. Helsinki: Suomalaisen Kirjallisuuden Seura.

Reichling, Dietrich (toim.) 1893: Das Doctrinale des Alexander de Villa Dei. Kritischexegetische Ausgabe. Monumenta Germaniae paedagogica. Nide 12. Berlin: Hofmann \& Comp.

SPIEgel, BernhARD 1864: Hermann Bonnus, erster Superintendent von Lübeck und Reformator von Osnabrück. Nach seinem Leben und seinen Schriften bearbeitet. Leipzig: Rossbergsche Buchhandlung.

Vihonen, SAKARI 1978: Suomen kielen oppikirja 160o-luvulla. Kieliopillinen ajattelu 16oo-luvun suomen kielen oppikirjoissa. Studia philologica Jyväskyläensia 11. Jyväskylä: Jyväskylän yliopisto.

WiIK, KALEVI 1989: Suomen kielen morfofonologian historia 1. Nominien taivutus 1649-1820. Turku: Turun yliopisto.

Kirjoittajien yhteystiedot: etunimi.sukunimi@helsinki.fi

\section{Osallistu Virittäjän lukijakyselyyn!}

Virittäjä teettää lukijakyselyn loka-marraskuussa 2017. Haluamme tietää muun muassa siitä, kuinka tärkeänä lukijat pitävät painetun lehden säilyttämistä verkkolehden rinnalla. Keräämme vastauksia pääasiassa sähköisellä lomakkeella, johon löytyy linkki esimerkiksi Virittäjän kotisivulta (ks. journal.fi/Virittäjä). Jos haluat vastata kyselyyn paperisella lomakkeella, ota yhteyttä kyselyn toteutuksesta vastaavaan Jenni Neuvoseen (etunimi.sukunimi@helsinki.fi). Virittäjä maksaa vastauslähetyksen postikulut. Kaikkien vastaajien kesken arvotaan kolme vuoden 2018 Virittäjän vuosikertaa. 